\title{
Index for Volume 95 of Plant Disease
}

AUTHOR AND SUBJECT INDEX. Page numbers of errata are in italic. $\mathrm{N}$ indicates disease note.

Abadie, C., 359N

Abang, M. M., 1192N

Abelleira, A., 776N, 1583N

Abies fraseri (Fraser fir), Phytophthora spp. on, 537

Abscissic acid (ABA), Xylella fastidiosa on grape and, 173

Acanthus mollis, Cercospora beticola on, in California, 224N

Acer palmatum, Cylindrocarpon macrodidymum on, in Virginia, $1592 \mathrm{~N}$

Achor, D., 755

Acibenzolar-S-methyl, Xanthomonas citri subsp. citri on grapefruit and, 725

Acidovorax avenae subsp. avenae, on white bird of paradise, $1474 \mathrm{~N}$

Acidovorax citrulli, on cucurbits

ELISA-based detection of, 1172

nonpathogenic Acidovorax citrulli strain for biological control of, 697

Actinidia chinensis (kiwifruit)

Cylindrocarpon liriodendri on, in Turkey, $76 \mathrm{~N}$

Pseudomonas syringae pv. actinidiae on in France, $1311 \mathrm{~N}$ in Spain, $1583 \mathrm{~N}$

Adaskaveg, J. E., 448

Adesemoye, A. O., $770 \mathrm{~N}, 1187 \mathrm{~N}$

Adhikari, T. B., 582, 1558

Adiyaman, T., 24

Adkins, S., 360N, 755, 881N

Adkins, S. T., $1586 \mathrm{~N}$

Aeonium arboreum, Phytophthora nicotianae on, in Italy, $362 \mathrm{~N}$

Aerobiological modeling, for predicting

Phakopsora pachyrhizi incursions, 1346

Afghan, S., $1581 \mathrm{~N}$

Aflatoxin, atoxigenic Aspergillus flavus isolates

for reduction of, 212

Agindotan, B. O., 616N

Agrostis stolonifera (creeping bentgrass) resistance of closely mown to snow mold pathogens, 839

Waitea circinata var. circinata on, in Arizona, 492N

Waitea circinata var. circinata on, in New Jersey, $78 \mathrm{~N}$

Agudelo, P., 74N, 835

Aguilar, M. I., 615N, 1028N

Aguin, O., $776 \mathrm{~N}$

Aguín, O., 1583N

Aguín Casal, O., 221N, 1315N

Agustí-Brisach, C., 76N, 803, 874N, 1028N

Ahmed, S., 1192N

Ahn, T.-Y., 589

Ahondokpê, B., 357N

Ahonsi, M. O., 616N

Aiello, D., 877N, 1030N, 1194N, 1588N

Aime, M. C., 353N

Al Rwahnih, M., 657

Alabi, O. J., 613N

Alaniz, S., $1028 \mathrm{~N}$

Albugo candida

on Indian mustard, in Australia, 712

on Lunaria аппиа, $72 \mathrm{~N}$

on perennial pepperweed, in California, $876 \mathrm{~N}$

Aletà, N., 1565

Alfalfa. See Medicago sativa

Alfalfa mosaic virus (AMV), in Viburnum tinus, in Chile, $1198 \mathrm{~N}$

Alfaro-Fernández, A., 75N

Ali Triki, M., 770N
Alioto, D., 611N

Allen, J., 1589N

Allende-Molar, R., 1195N

Allium spp.

A. серa (onion)

Botrytis squamosa on, 504

Enterobacter cloacae on, in New York, $1581 \mathrm{~N}$

Iris yellow spot virus in: in Kenya and Uganda, 1195N; in New York, 735

Phytophthora nicotianae on, in United States, $1028 \mathrm{~N}$

Pseudomonas syringae pv. porri on, in Korea, $1311 \mathrm{~N}$

Iris yellow spot virus in, $1319 \mathrm{~N}$

A. sativum (garlic)

Garlic virus $X(\mathrm{GarV}-\mathrm{X})$ in, in India, $1197 \mathrm{~N}$

Shallot latent virus in, in Brazil, 227N

Almond. See Prunus dulcis

Al-Mughrabi, K. I., 873N

Al-Saady, N. A., 360N

Al-Subhi, A. M., 226N, 360N

Alternaria spp.

A. alternata

on Basella alba, in India, 1476N

on Houttuynia cordata, in China, 359N on pistachio, QoI fungicide-resistant, 178 on potato, in South Africa, 363N

A. japonica, on rocket, in Italy, $1316 \mathrm{~N}$

A. tenuissima, on Eleutherococcus

senticosus, in China, 493N

Amaranthus spp. (pigweeds, waterhemp)

16SrI group phytoplasma associated with, $871 \mathrm{~N}$

Cucurbit yellow stunting disorder virus in, in Florida, 360N

in pumpkin and soybean, biological control of, 469

Amatulli, M. T., 76N, 225N, 873N, 880N

Ambrosia trifida (giant ragweed),

Golovinomyces ambrosiae on, in Korea, $1480 \mathrm{~N}$

Amelanchier alnifolia (juneberry),

Gymnosporangium nelsonii on, in Michigan, $770 \mathrm{~N}$

Anacardium occidentale (cashew),

Xanthomonas spp. on, polyphasic

characterization of pigmented strains, 793

Anders, M. M., 990

Andersen, P. C., 166

Anderson, J. A., 1032N

Andrade-Piedra, J. L., 839

Angel's trumpet. See Brugmansia spp.

Annamalai, M., 755

Ansley, R. J., 4

Aphids

Citrus tristeza virus and, stem pitting and, 913

Potato virus $Y$ strain transmission and, 1279

Soybean dwarf virus acquisition and transmission and, 945

Aphis glycines (soybean aphid), Soybean dwarf virus acquisition and transmission and, 945

Appel, D. N., 888

Apple. See Malus spp.

Apple cactus. See Cereus peruvianus monstruosus

Apricot. See Prunus spp.

Aquilegia flabellata (fan columbine)

Phoma aquilegiicola on, in Italy, $880 \mathrm{~N}$

Sclerotinia sclerotiorum on, in Italy, $1481 \mathrm{~N}$

Arabian pea. See Bituminaria bituminosa

Arachis hypogaea (peanut) leaf spots of, resistance and yield in genotypes in U.S. and Bolivia, 263

Neocosmospora vasinfecta var. africana on, in China, $1480 \mathrm{~N}$

Arbuscular mycorrhiza, biochar, Fusarium crown and root rot in asparagus and, 960

Arbutus unedo (strawberry tree), Colletotrichum spp. on, in Italy, $1588 \mathrm{~N}$

Aregbesola, A., 618N

Aretakis, K. C., 78N

Ariatti, A., 1346

Armengol, J., 76N, 615N, 803, 874N, 1028N, 1040

Armillaria spp., effects of hydrolyzable tannins on in vitro growth of, 1255

Arslan, M., 1035N

Artemisia dracunculus (tarragon), Fusarium solani on, in California, $768 \mathrm{~N}$

Artichoke, Pectobacterium carotovorum subsp. carotovorum in, in China, $1026 \mathrm{~N}$

Aryamanesh, N., 226N

Asano, T., 1270

Ascochyta blight, pathogen survival in field-

pea-cropping soils of Australia, 1217

Ash, European. See Fraxinus excelsior

Asparagus, Fusarium spp. on, replant soils, biochar amendments and, 960

Aspergillus flavus, on corn, atoxigenic isolates to reduce contamination of maize in Kenya, 212

Aster yellows. See Candidatus Phytoplasma asteris

Atallah, Z. K., 784, 1224

Attar, N., 1321N

Audusseau, C., $1311 \mathrm{~N}$

Auger, J., 683

Aulacophora foveicollis (red melon beetle), Snake melon asteroid mosaic virus transmission and, 153

Avena spp. (oat), Puccinia coronata f. sp. avenae on, virulence in United States 20062009, 1258

Avocado. See Persea americana

Ayala-Escobar, V., 775N

Ayres, A. J., 104

Azalea. See Rhododendron spp.

Azoxystrobin, for Monilinia fructicola, 821

Babiker, E. M., 304

Babu, A. G. C., 1033N

Bacillus simplex, for control of Phytophthora erythroseptica, on potato, 24

Bactrocera oleae (olive fruit fly), on olive, in Tunisia, $770 \mathrm{~N}$

Badalà, F., 769N

Bag, S., 1319N

Bagheri, A. N., 419

Bagyanarayana, G., 1476N

Bahrami, H. R., 419

Bai, Q., 771N

Bai, Q. R., 493N

Baino, O. M., 1477N

Baker, C. A., 755

Bakonyi, J., 1193N

Balestra, G. M., 221N

Ballard, E. L., 1109

Banana. See Musa spp.

Banana streak virus (BSV), novel rolling-circle amplification method for detection of and discrimination between episomal and integrated virus sequences, 57

Bananej, K., 38

Bandyopadhyay, R., 43, 212, 618N 
Baranwal, V. K., 1197N

Barbetti, M. J., 712, 1590N

Barbieri, M., 1339

Barbosa, J. C., 363N

Barboza, N., 497N, 1482N

Bardas, G. A., 666

Bardin, M., 719

Barkley, N. A., 1385

Barley. See Hordeum vulgare

Barley mild mosaic virus (BaMMV) and Barley yellow mosaic virus (BaYMV), Polymyxa graminis $\mathrm{f}$. sp. temperata as vector of, in

Czech Republic, 353N

Barnes, C. W., 1346

Barooti, S., $882 \mathrm{~N}$

Barreto, R. W., 1588N

Basella alba (malabar spinach)

Alternaria alternata on, in India, $1476 \mathrm{~N}$

Bipolaris sp. on, in Florida, 880N

Basigalup, D., 771N

Basil, sweet. See Ocimum basilicum

Bassanezi, R. B., 104

Bates, C. A., 1056

Batool, A., $1581 \mathrm{~N}$

Batzer, J. C., 368, 729

Bau, H. J., $1581 \mathrm{~N}$

Bau, H.-J., $1036 \mathrm{~N}$

Baum, M., 1192N

Bayaa, B., 1192N

BCMV. See Bean common mosaic virus

Bean. See Phaseolus spp.

Bean common mosaic virus (BCMV), in Lablab purpureus, in India, $881 \mathrm{~N}$

Bean golden yellow mosaic virus (BGYMV), in bean crops, in Nicaragua, 901

Bean pod mottle virus (BPMV), in soybean within-field temporal and spatial dynamics, in Spain, 126

Phomopsis longicolla infection and, 530, cover photo: May

Beckerman, J. L., 921, 927

Bedendo, I. P., 363N

Beer, S. V., $1581 \mathrm{~N}$

Beet. See Beta vulgaris

Beet severe curly top virus (BSCTV), in

Jalapeño Pepper, in Mexico, 778N

Beikzadeh, N., $1485 \mathrm{~N}$

Beirn, L. A., 1547

Bejerman, N., 771N

Belgrove, A., 951

Belkheir, K., 495N

Bell pepper. See Capsicum anпиит

Bellaloui, N., 1159

Bender, C. M., 611N

Bennett, R. S., 967

Benson, D. M., 537, 1013

Bentgrass, creeping. See Agrostis stolonifera

Bereczky, Z., 361N

Berenji, J., $1035 \mathrm{~N}$

Bergamot. See Monarda didyma

Bergstrom, G. C., 1032N, 1189N, 1192N, 1587N

Bernal, A., $875 \mathrm{~N}$

Berner, D., $1586 \mathrm{~N}$

Berner, D. K., 577

Berretta, M. F., 774N, 1476N, 1478N

Bertetti, D., 225N, 873N, 877N, 878N, 880N, $1191 \mathrm{~N}, 1317 \mathrm{~N}, 1481 \mathrm{~N}$

Bertoldo, C., $1315 \mathrm{~N}, 1316 \mathrm{~N}$

Bese, G., 363N

Besoain, X., 1032N

Best, G. S., 1056

Beta vulgaris (sugar beet), Erysiphe polygoni on, in Michigan, $494 \mathrm{~N}$

BGYMV. See Bean golden yellow mosaic virus

Bhattacharyya, M. K., 1420

Bidens mottle virus (BiMoV), in Calendula officinalis, in Taiwan, 362N

Bidens sulphurea, Botrytis cinerea on, in Brazil, $1588 \mathrm{~N}$
Biggs, A. R., 368

Biltberry. See Vaccinium myrtillus

BiMoV. See Bidens mottle virus

Bin, S. Y., 1190N

Biochar, mycorrhizal associations and Fusarium

crown and root rot in asparagus and, 960

Biological control agents

Colletotrichum lineola, for control of swallow-worts, $1586 \mathrm{~N}$

for control of Phytophthora erythroseptica, on potato, 24

Fusarium oxysporum, for control of Fusarium oxysporum f. sp. cubense on banana, 951

nonpathogenic Acidovorax citrulli strain, for control of Acidovorax citrulli on cucurbits, 697

Pichia anomala strain $\mathrm{K}$

for control of apple blue mold, screening UV protectants for preharvest application, 311

for powdery mildew on squash and cantaloupe, 461

Pseudomonas fluorescens, for control of Fusarium oxysporum f. sp. cubense on banana, 951

Synchytrium solstitiale, for yellow starthistle, 907

waterhemp and pigweed control in pumpkin and soybean, 469

Bipolaris spp.

on malabar spinach, in Florida, 880N

B. oryzae, on switchgrass, in New York, $1192 \mathrm{~N}$

B. sorokiniana

on switchgrass, in Tennessee, $1195 \mathrm{~N}$ on wheat: distribution and prevalence in Montana, 1099; and Fusarium pseudograminearum, population dynamics between using real-time qPCR, 1089

B. spicifera on sorghum, in Turkey, $495 \mathrm{~N}$ on switchgrass, in United States, 1191N

Bird of paradise. See Strelitzia nicolai

Birithia, R., 1195N

Biscogniauxia mediterranea, on chestnut-leaved oak, in Iran, 876N

Bittersweet nightshade. See Solanum dulcamara

Bituminaria witches'-broom phytoplasma

(BiWB), on Arabian pea, in Australia, 226N

Bjerke, J. M., 614N

Black sigatoka disease. See Mycosphaerella fijiensis

Blackberry. See Rubus sp.

Blanco-Meneses, M., 673

Blandón-Díaz, J. U., 839

Blomquist, C. L., 224N, 356N, 361N, 872N, $1478 \mathrm{~N}$

Blount, A., 317

Blueberry. See Vaccinium corymbosum

Bluegrass, annual. See Poa annua

$\mathrm{BN}$ (bois noir) phytoplasma. See Bois noir

Boahen, S., 492N

Boal, R. J., 72N, 1075

Bockus, W. W., 554

Boehmeria nivea, Colletotrichum higginsianum on, in China, $1318 \mathrm{~N}$

Boeremia exigua var. exigua, on pyrethum, in Australia, $1478 \mathrm{~N}$

Bois noir (BN) phytoplasma, on grape, in Croatia, 353N

Boiteux, L. S., 1196N, 1318N

Bóka, K., 363N

Bollig, K., 394

Bonasera, J. M., 1581N

Bonde, M. R., 577

Bonman, J. M., 582

Bonos, S. A., $78 \mathrm{~N}$
Borate, for control of Colletotrichum

gloeosporioides on mango, 63

Boscalid, for Botrytis cinerea on strawberry, detection and molecular characterization of resistant isolates, 1302

Botha, W. J., 1153

Bothe-Goralczyk, M. A., 751

Botryosphaeria spp.

B. dothidea

on blueberry, in Korea, 227N

on Japanese apricot, in Taiwan, 77N on pecan, in China, $1319 \mathrm{~N}$

B. obtusa, on grape, in China, $616 \mathrm{~N}$

B. rhodina, on grape, on China, $219 \mathrm{~N}$

on peach, in China, 1378

Botrytis spp.

B. cinerea

on apple, in Greece, 666

on blackberry, in South Carolina, 1481N, $1592 \mathrm{~N}$

on grape: in Chile, 683; gibberellic acid for management of, 269 resistance to multiple fungicides in $\mathrm{N}$. German small-fruit production, 1263 on Schisandra chinensis, in China, $768 \mathrm{~N}$ on yellow cosmos, in Brazil, 1588N

B. cinerea, on strawberry boscalid-resistant isolates, 1302 in South Carolina, 1482N

B. hyacinthi, on pineapple lily, in California, $224 \mathrm{~N}$

B. squamosa, on onion, 504

Bougainvillea spectabilis, Passalora

bougainvilleae on, in Mexico, $775 \mathrm{~N}$

Bowden, R. L., 478

Boyer, C., 774N, 1311N, 1312N

Boyles, M., 614N

Bozkova, V., 1320N

BPMV. See Bean pod mottle virus

Brachypodium distachyon (purple false brome

grass), Puccinia spp. on, 1339

Bradley, C. A., 189, 616N, 1318N

Brady, C. R., 853

Brassica spp.

B. chinensis (field mustard), Turnip ringspot virus in, in Taiwan, $1036 \mathrm{~N}$

B. juncea (Indian mustard), Albugo candida

on, in Australia, 712

B. oleracea (cabbage)

Pectobacterium carotovorum subsp. carotovorum on, in Malaysia, $491 \mathrm{~N}$

Pseudomonas cannabina pv. alisalensis on, in California, $71 \mathrm{~N}$

broomrape and, in India, $75 \mathrm{~N}$

B. napus (canola, oilseed rape)

branched broomrape on, in Greece, $1322 \mathrm{~N}$

Candidatus Phytoplasma asteris on, in Poland, 1475N

Leptosphaeria maculans on, in Oklahoma, 614N

Xanthomonas campestris pv. campestris on, sources of resistance to, 292

Pseudomonas cannabina pv. alisalensis on,

in Australia, $1027 \mathrm{~N}$

Brazee, N. J., 1255

Brenneria salicis, on white willow, in Italy, $772 \mathrm{~N}$

Bridges, W. C. Jr., 811

Briere, S., $1591 \mathrm{~N}$

Brlansky, R. H., 913

Brodbeck, B. V., 166

Broders, K. D., 401

Brodeur, L., 504

Brooks, S. A., 990

Brooks, W. S., 19

Broomrape. See Orobanche spp.

Brostaux, Y., 311

Broussonetia papyrifera (paper mulberry) 
Cochliobolus sativus on, in China, $1586 \mathrm{~N}$

Colletotrichum gloeosporioides on, in

China, $880 \mathrm{~N}$

Brown, J. K., 73N, 120

Brown citrus aphid. See Toxoptera citricida

Bruckart, W. L. III, 907

Brugmansia spp.

Colombian datura virus in, 755

Tomato apical stunt viroid in, in Belgium, $495 \mathrm{~N}$

Brurberg, M. B., 355N, 1187N

Bryson, P. K., 772N

BSCTV. See Beet severe curly top virus

BSV. See Banana streak virus

Buck, J. W., 325

Buckley, R., 78N

Budak, H., 223N

Budak, U., 497N

Bulajic, A., 226N, 491N, 719, 882N, 1035N

Bull, C. T., 71N, 1027N

Bunt. See Tilletia spp.

Burks, S., 888

Burnip, G. M., 617N

Burpee, L. L., 490N, 515

Bursaphelenchus xylophilus (pine wood nematode), on Pinus pinaster, in Spain, 776N

Byamukama, E., 126

Byrne, J., 614N

Cabbage. See Brassica oleracea

CABMV. See Cowpea aphid-borne mosaic virus

Cabral, P. G. C., $1194 \mathrm{~N}$

Cacciola, S. O., 358N, 362N, 769N

Cactus, apple. See Cereus peruvianus monstruosus

Cadle-Davidson, L., 202

Cadophora luteo-olivacea, isolation from vineyard weeds, 803

Cai, J.-H., 1483N

Calathea picturata, Exserohilum rostratum on, in Taiwan, $1033 \mathrm{~N}$

Calendula officinalis, Bidens mottle virus in, in Taiwan, 362N

Calitz, F. J., 1153

Calonectria colhounii on blueberry, in United States, $1187 \mathrm{~N}$ on Rhododendron spp., in Belgium, 1477N

Calopogonium golden mosaic virus, in bean crops, in Nicaragua, 901

Camele, I., 72N

Campbell-Nelson, K., 51

Campylocarpon spp., on grape propagation process and, 1040 in Spain, $1028 \mathrm{~N}$

Canary Island date palm. See Phoenix canariensis

Candidatus Liberibacter

Ca. L. africanus analysis of a prophage gene frequency revealed population variation of, 431 on citrus, in South Africa, 1026N

Ca. L. solanacearum on potato, improved PCR detection of, 1542 on tomato, in Mexico, 1026N

Candidatus Phytoplasma

Ca. P. aurantifolia, on lime, 419

Ca. P. brasiliense, on Sida sp., in Brazil, $363 \mathrm{~N}$

Ca. P. asteris

on oilseed rape, in Poland, $1475 \mathrm{~N}$

on potato: in Alaska, $767 \mathrm{~N}$; in China, $777 \mathrm{~N}$

witches'-broom disease of soybean and, $492 \mathrm{~N}$, cover photo: April

Candresse, T., 1196N

Canna lily, Puccinia thaliae on, in Louisiana, $353 \mathrm{~N}$
Canola. See Brassica napus

Cantaloupe. See Cucumis melo

Cao, T., 158

Cao, W., $1591 \mathrm{~N}$

Capsicum annuum (pepper)

Beet severe curly top virus in, in Mexico, $778 \mathrm{~N}$

Colletotrichum coccodes on, in India, 1584N

Cucumber mosaic virus in, 2b-deficient mutant and limited, asymptomatic infection, 331

Fusarium lactis on, in Korea, 1476N

Fusarium proliferatum on, in Trinidad, $1313 \mathrm{~N}$, cover photo: October

Glomerella acutata on, in China, $219 \mathrm{~N}$

Pepper mottle virus in, in Taiwan, 617N

Phytophthora capsici on, cover photo: May

Tomato chlorosis virus in, in Costa Rica, $1482 \mathrm{~N}$

Tomato spotted wilt virus in, in Montenegro, $882 \mathrm{~N}$

Capsicum chinense (hot pepper), Cercospora apii on, in Brazil, 1194N

Cárdenas, M. E., 875N

Carica papaya (papaya)

Colletotrichum spp. on, in Trinidad, 1244

Erwinia papayae-like bacterium on, $70 \mathrm{~N}$

Erysiphe diffusa, Oidium neolycopersici, and

Podosphaera xanthii on, in Taiwan, $1188 \mathrm{~N}$

group 16SrXII phytoplasma in, in Taiwan, $1581 \mathrm{~N}$

Carisse, O., 504, 1167

Carmichael, D. J., 767N

Carnation mottle virus (CarMV)

in lisianthus, in Taiwan, 1036N

in Phalaenopsis orchids, 354N

Carob. See Ceratonia siliqua

Carrieri, R., $611 \mathrm{~N}$

Carrillo-Fasio, J. A., 1195N

Carrión, E., $1478 \mathrm{~N}$

Carrot. See Daucus carota

Carson, M. L., 1528

Cartea, M. E., 292

Carthamus tinctorius (safflower) Colletotrichum simmondsii on, 79N

Puccinia carthami on, cover photo: March

Carya cathayensis (pecan), Botryosphaeria

dothidea on, in China, 1319N

Cascone, G., 195

Cashew. See Anacardium occidentale

Casler, M. D., 847

Castañares, E., 496N

Castañeda-Vildozola, A., 775N

Castello, I., 195

Castillo, J. D., 490N

Castlebury, L. A., 357N, 770N, 772N

Castor bean. See Ricinnus communis

Castro, A., 1192N

Catharanthus roseus (Madagascar periwinkle), Spiroplasma citri on, in Southeast Asia, $1312 \mathrm{~N}$

Cating, R. A., 74N

Cavin, C., $1586 \mathrm{~N}$

CbVd-2. See Coleus blumei viroid 2

CChMVd. See Chrysanthemum chlorotic mottle viroid

CCYV. See Cucurbit chlorotic yellows virus

CDV. See Colombian datura virus

Cebrián, M. C., $75 \mathrm{~N}$

Cedar, Lebanon. See Cedrus libani

Cedar, stinking. See Torreya taxifolia

Cedrus libani (Lebanon cedar), Herpotrichia juniperi on, in Turkey, $222 \mathrm{~N}$, cover photo: February

Centaurea solstitialis, Synchytrium solstitiale on, 907

Ceratocystis fagacearum, changes and successes in managing in U.S., 888
Ceratocystis fimbriata, on pomegranate, in China, $776 \mathrm{~N}$

Ceratonia siliqua (carob), Diplodia olivarum on, in Italy, $776 \mathrm{~N}$

Cercospora spp.

C. apii, on hot pepper, in Brazil, 1194N

C. arachidicola, on peanut, resistance and yield in genotypes in U.S. and Bolivia, 263

C. beticola, on Acanthus mollis, in

California, $224 \mathrm{~N}$

C. coffeicola, on castor beans, in Brazil, $1479 \mathrm{~N}$

C. sojina, on soybean, in Virginia, $878 \mathrm{~N}$

C. zeae-maydis, on corn, QoI fungicideresistant, 189

Cercosporidium personatum, on peanut, resistance and yield in genotypes in U.S. and Bolivia, 263

Cereus peruvianus monstruosus (apple cactus), Fusarium oxysporum on, in Italy, 877N

CGRMV. See Cherry green ring mottle virus

Chai, W., $1482 \mathrm{~N}$

Chandelier, A., 220N

Chandra Nayaka, S., 881N

Chang, C. A., $617 \mathrm{~N}$

Chang, L. C., 360N

Chang, W. C., 1581N

Chang, Y.-S., 1036N

Chao, C. H., 874N

Chapara, V., 691, 1318N

Chapman, K. S., 921

Charkowski, A. O., 232

Chattaoui, M., 770N

Chauhan, J. S., 75N

Chávez, E. R, 1032N

Chayote. See Sechium edule

Chellemi, D. O., 755

Chen, B., 1320N

Chen, C. C., $617 \mathrm{~N}$

Chen, C. M., 492N

Chen, C.-C., 354N, 1036N

Chen, C.-M., 767N

Chen, F. P., 1481N

Chen, J., 222N, 431, 1318N

Chen, J.-P., 1063

Chen, K., 1586N

Chen, Q.-Y., 612N

Chen, R.-S., 1188N

Chen, S. N., 225N

Chen, S. S., 78N

Chen, W., 1031N, 1480N

Chen, W. J., 354N, 362N

Chen, W. Q., 774N

Chen, X.-Y., 1284

Chen, Y., $225 \mathrm{~N}$

Chen, Y. H., 871N

Chen, Y. K., 1581N

Chen, Y.-K., 1036N

Cheng, J.-A., 1063

Cheng, M., 767N, 777N, 871N

Cheng, Y. H., 617N

Cheng, Y. Q., 222N

Chern, L. L., 1033N

Cherry. See Prunus persicola

Cherry green ring mottle virus (CGRMV), in

cherry and peach, in China, 1319N

Cherry laurel. See Prunus laurocerasus

Cherry tomato. See Lycopersicon esculentum var. cerasiforme

Chiang, C. H., 617N

Chickpea. See Cicer arietinum

Chickpea chlorotic stunt virus (CpCSV), in

legumes, in Tunisia, $1321 \mathrm{~N}$

Chicoine, D. R., 202

Chicory. See Cichorium intybus

Chili pepper. See Capsicum annuum

Chilli veinal mottle virus (ChiVMV), in tobacco, in China, 357N

Chiu, K. Y., 78N 
ChiVMV. See Chilli veinal mottle virus

Cho, M. S., 589

Cho, S. E., 1317N, 1480N, 1590N

Choi, H. S., $220 \mathrm{~N}$

Choi, H.-W., 1476N

Choi, I. Y., 227N

Choi, O., 616N

Cholastová, T., 79N

Chorbadjian, R. A., 1193N, 1198N

Chrysanthemum chlorotic mottle viroid

(CChMVd), in chrysanthemum, in China, $1320 \mathrm{~N}$

Chrysanthemum stunt viroid (CSVd), in

Argyranthemum frutescens, in France, 1196N

Chung, K.-R., 1590N

Cicer arietinum (chickpea)

Didymella rabiei on, in Syria, 1192N

Ramulispora sorghi on, 860

Cichorium intybus (chicory), Fusarium

oxysporum on, in Italy, $496 \mathrm{~N}$

Cinelli, T., 74N

Cirvilleri, G., 1030N

Citrullus lanatus (watermelon)

Cucurbit chlorotic yellows virus in, in China, $73 \mathrm{~N}$

Didymella bryoniae on, in Tanzania, 768N

Erwinia tracheiphila on, in New Mexico, $1583 \mathrm{~N}$

Podosphaera xanthii on, in Florida, 1586N; cover photo: December

Citrus psorosis virus (CPsV), in citrus, in New

Zealand, 775N

Citrus spp.

C. aurantifolia (Mexican lime),

Xanthomonas citri pv. citri on, in Senegal, $1311 \mathrm{~N}$

Candidatus Liberibacter africanus on, in South Africa, 1026N

Candidatus Liberibacter asiaticus on, analysis of a prophage gene frequency revealed population variation of, 431

Candidatus Phytoplasma aurantifolia on, 419

Citrus psorosis virus and Citrus viroid III in, in New Zealand, $775 \mathrm{~N}$

citrus sudden death in, transmission by graft inoculation and prevention of transmission by individual insect-proof cages, 104

Citrus tristeza virus in, transmission by brown citrus aphid, stem pitting and, 913

C. clementina, Septoria citri on, in Italy, $873 \mathrm{~N}$

Eutypella spp. on, in California, 1187N

C. grandis (pomelo), Lasiodiplodia theobromae on, in China, $1190 \mathrm{~N}$

Haematonectria haematococca on, in Philippines, $1590 \mathrm{~N}$

lime

Candidatus Phytoplasma aurantifolia on, 419

Xanthomonas citri pv. citri on, in

Senegal, $1311 \mathrm{~N}$

C. paradisi (grapefruit), Xanthomonas citri pv. citri on

imidacloprid, thiamethoxam, and

acibenzolar- $S$-methyl for control of, 725

in Senegal, $1311 \mathrm{~N}$

Spencermartinsia viticola, Neofusicoccum australe, and $N$. parvum on, in California, $770 \mathrm{~N}$

sweet orange, October syndrome in, cover photo: March

C. volkameriana (Volkamer lemon), Sclerotinia sclerotiorum on, in Italy, $1030 \mathrm{~N}$

Citrus tristeza virus (CTV), transmission by

brown citrus aphid, stem pitting and, 913

Citrus viroid IIII (CVd-III), in citrus, in New
Zealand, $775 \mathrm{~N}$

Ciuffo, M., 882N, 1484N

Cladobotryum mycophilum, on king oyster mushroom, in Spain, 1030N

Clarke, B. B., 78N, 1547

Clary, M., $1583 \mathrm{~N}$

Clavibacter michiganensis subsp. michiganensis on corn, in Texas, $73 \mathrm{~N}$

on tomato

in Italy, $221 \mathrm{~N}$, cover photo: February as seedborne pathogen, 1328

Clements, J., 1584N

Clements, J. M., 1179

Climate change, plant diseases in the developing world and, 1204

Clover, Soybean dwarf virus in, soybean aphid and, 945

Clover, G. R. G., 617N, 775N, 1484N

Clover proliferation group phytoplasmas

(16SrVI-A), on potato, in China, 871N

Cochliobolus sativus, on paper mulberry, in

China, $1586 \mathrm{~N}$

Coelho, L., 317

Coffey, M. D., 337

Cofré, G., 683

Cohen, Y., 874N

Coleus blumei, Coleus blumei viroid 2 in, in China, 494N

Coleus verschaffeltii, Verticillium dahliae on, in Italy, $878 \mathrm{~N}$

Colletotrichum spp.

C. gloeosporioides

on mango, borate for control of, 63 on paper mulberry, in China, $880 \mathrm{~N}$ on pistachio, in China, 1314N on pomegranate, in Greece, $872 \mathrm{~N}$

C. graminicola, on corn, tillage, crop rotation, and hybrid effects on, 601

C. higginsianum, on Boehmeria nivea, in China, $1318 \mathrm{~N}$

C. lindemuthianum, on dry bean, prevalent races and resistance sources in North Dakota, 408

C. lineola, on swallow-worts, from Russia, $1586 \mathrm{~N}$

C. navitas, on switchgrass, in New York, $1032 \mathrm{~N}$

C. simmondsii, on safflower, in Czech Republic, $79 \mathrm{~N}$

C. acutatum on grape, detection and monitoring by real-time PCR, 298 on yellow dryad, in Switzerland, 1031N

C. caudatum, on Indiangrass, in New York, $1189 \mathrm{~N}$

C. coccodes, on chili pepper, in India, $1584 \mathrm{~N}$

C. fragariae, on cyclamen, in North Carolina, $1480 \mathrm{~N}$

on papaya, in Trinidad, 1244

on strawberry tree, in Italy, $1588 \mathrm{~N}$

Colocasia esculenta (taro), Phytophthora colocasiae on, in Nigeria, $618 \mathrm{~N}$

Colombian datura virus (CDV), in Brugmansia spp., 755

Columbine, fan. See Aquilegia flabellata

Comstock, J. C., 357N, 640

Condori, M. M., 263

Coneflower, purple. See Echinacea pallida

Conley, S. P., 1401

Connell, J. H., 158

Consolie, N. H., 202

Constantelos, C., 618N

Cook, G., 767N, 1026N

Cooley, D., $1584 \mathrm{~N}$

Cooley, D. R., 368, 1179

Copes, W. E., 705

Córdoba-Sellés, C., 75N

Corn. See Zea mays
Cornacchione, M., 771N

Cornish, D. A., 70N, 1311N

Corrêa, A. S., 354N

Correll, J. C., 876N

Cosic, J., 612N

Cosmos

Botrytis cinerea on, in Brazil, 1588N

Podosphaera fusca on, in Malaysia, 495N

Verticillium dahliae on, in California, 361N

Cotton. See Gossypium spp.

Cotty, P. J., 212

Cowger, C., 561

Cowpea. See Vigna sinensis

Cowpea aphid-borne mosaic virus (CABMV) in passion flower, transformation and resistance to, 1021

in sesame, in Paraguay, 613N

Cox, K., 1179

Cox, K. D., 828, 1584N, 1589N

CpCSV. See Chickpea chlorotic stunt virus

CPsV. See Citrus psorosis virus

Cramer, C. S., 1319N

Cranberry. See Vaccinium macrocarpon

Crane, J. H., 1589N

Crassula ovata (jade), Fusarium oxysporum on, in Italy, 1191N

Creemers, P., 279, 1029N

Cronartium ribicola on black currant, in Connecticut, $1589 \mathrm{~N}$ on pine, in Arizona, $494 \mathrm{~N}$

Crop rotation

Colletotrichum graminicola on corn and, 601

rice grain smuts and, 990

Verticillium dahliae on potato and, 568

Crosslin, J. M., 1483N

Crouch, J. A., 624, 1547

Crous, P. W., 368, 876N

Crow, W. T., 1308

Cruse-Sanders, J., 633

Cryptovalsa ampelina, on grape, in Chile, $490 \mathrm{~N}$

Csinos, A. S., 490N

Cubeta, M. A., 490N, 705

Cucumber. See Cucumis sativus

Cucumber mosaic virus, in pepper, 2b-deficient mutant and limited, asymptomatic infection, 331

Cucumis spp. (melon, cucumber)

Cucurbit chlorotic yellows virus in, $73 \mathrm{~N}$,

cover photo: January

C. melo (cantaloupe)

Phomopsis cucurbitae on, in Italy, $1317 \mathrm{~N}$

Podosphaera xanthii on, 461

C. melo (melon), Cucurbit chlorotic yellows

virus in, in China, 354N

C. melo (muskmelon)

Cucurbit chlorotic yellows virus in, in Sudan, 1321N

Erwinia tracheiphila on, delaying row covers for suppression of, 725

C. sativus (cucumber)

Cucurbit chlorotic yellows virus in: in

China, 73N; in Sudan, 1321N

Hop stunt viroid in, in Finland, 615N

Pectobacterium carotovorum subsp. carotovorum on, in Malaysia, 1474N

Phytophthora melonis on, 455

Tomato leaf curl New Delhi virus in, in Indonesia, $1485 \mathrm{~N}$

Cucurbit aphid-borne yellows virus (CABYV) in oilseed pumpkin, in Serbia, 1035N in squash, in Czech Republic, $220 \mathrm{~N}$

Cucurbit chlorotic yellows virus (CCYV) in cucumber and muskmelon, in Sudan, $1321 \mathrm{~N}$

in cucurbits, in China, 73N

in melon, 354N, cover photo: January

Cucurbit yellow stunting disorder virus 
(CYSDV), in pigweed, in Florida, 360N

Cucurbita spp.

Acidovorax citrulli on

ELISA-based detection of, 1172 nonpathogenic Acidovorax citrulli strain

for biological control of, 697

Cucurbit chlorotic yellows virus in, in China, $73 \mathrm{~N}$

C. maxima (pumpkin), Didymella bryoniae on, in Tanzania, $768 \mathrm{~N}$

C. moschata, Pseudoperonospora cubensis on, in Czech Republic, $878 \mathrm{~N}$, cover photo: July

C. pepo (pumpkin, squash)

Cucurbit aphid-borne yellows virus in: in Czech Republic, 220N; in Serbia, $1035 \mathrm{~N}$

Erwinia tracheiphila on, in New Mexico, $1583 \mathrm{~N}$

pigweed and waterhemp in, biological control of, 469

Podosphaera xanthii on, 461

Squash mosaic virus in, in Czech Republic, 1321N

Pseudoperonospora cubensis on formation and infectivity of oospores, $874 \mathrm{~N}$

in Michigan, dynamics in commercial fields, 1392

Snake melon asteroid mosaic virus in, 153

Watermelon mosaic virus in, genetic

diversity in Slovakia and Iran, 38

Cuellar, W. J., 355N

Cuesta, M. J., 361N, 876N

Cui, H. G., 1483N

Culbreath, A. K., 263

Culjak, T. Gotlin, 883N

Cummings, T. F., 285

Cupressus macrocarpa (Monterey cypress), Seiridium unicorne on, in California, 619N

Curcuma wenyujin, Nigrospora sphaerica on, in China, 1190N, cover photo: September

Currant, black. See Ribes nigrum

CVd-III. See Citrus viroid IIII

Cyclamen persicum, Colletotrichum fragariae on, in North Carolina, $1480 \mathrm{~N}$

Cylindrocarpon spp

C. liriodendri, on kiwifruit, in Turkey, $76 \mathrm{~N}$

C. macrodidymum

on Acer palmatum, in Virginia, 1592N isolation from vineyard weeds, 803

C. pauciseptatum on grape, in Spain, 361N

on Pinus radiata, in Spain, 874N

on grape

propagation process and, 1040 in Spain, 361N

Cypress, Monterey. See Cupressus macrocarpa

CYSDV. See Cucurbit yellow stunting disorder virus

Dafalla, G., 153, 1321N

Dai, F. M., 354N, 362N

Dale, J. L., 57

Dallot, S., 1320N

Dalusky, M. J., 612N

Damsteegt, V. D., 913, 945

Dangl, G. S., 657

Danti, R., 619N

Dariva, J. M., 354N

Dart, N. L., 1592N

Daryono, B. S., $1485 \mathrm{~N}$

Date palm. See Phoenix canariensis

Datnoff, L. E., 317

Dattilo, A. J., 879N

Daucus carota (carrot), Sclerotium rolfsii on, in Korea, $1585 \mathrm{~N}$

Davidson, J. A., 1217

Davis, R. M., 1224
Dawson, T. E., $775 \mathrm{~N}$

Daylily, Puccinia hemerocallidis on, effect of postsymptom application of fungicides on urediniospore production by, 325

de Breuil, S., 771N

de Bruno Austin, L., 774N

de León, L., 1328

De S. Piedade, S. M., 1021

De Wolf, E. D., 554

Deadman, M. L., 360N

Debode, J., 1029N

Dee, M. M., 1191 N, $1195 \mathrm{~N}$

Degree-day model, for latent period of

Stagonospora nodorum on wheat, 561

del Mar Jiménez-Gasco, M., 1233

Del Ponte, E. M., 368

del Río Mendoza, L. E., 614N

del Rio-Mendoza, L. E., 408

Delaney, D. P., 1034N

Delaney, M. A., 1034N

Delécolle, B., 153

Delhaye, N., 220N

Della Rocca, G., 619N

Delobbe, L., 384

Delvalle, T. C., 1427

D'Emilio, A., 195

Demonty, E., 495N

Deng, M., $1031 \mathrm{~N}, 1480 \mathrm{~N}$

Deng, T. C., 617N

Deng, X., 431

Deogratias, J. M., 1196N

Deoxynivalenol (DON)

Fusarium graminearum chemotype of, resistance to initial infection and spread and, 31

Fusarium spp. on wheat, effects of integrating cultivar resistance and fungicide application, 554

Dervis, S., 219N, 1035N

Desbiez, C., 153

Detached tiller method, for assessment of resistance to Rhizoctonia solani on rice, 1507

DeTar, W. R., 967

Determann, R., 633

DeVries, R., 614N

Dharni, S., $1582 \mathrm{~N}$

Diaporthe eres, on blackberry, in Croatia, $612 \mathrm{~N}$

Dias, A. P. S., 485

Díaz, G. A., 490N, 1032N

Díaz Arias, M. M., 368, 1316N

Dickeya sp. See Pectobacterium chrysanthemi

Dickinson, M., 1312N

Dictamnus dasycarpus (fraxinella), Phoma

dictamnicola on, in China, $771 \mathrm{~N}$

Didymella spp.

on chickpea, in Syria, 1192N

on pea, pathogen survival in field-peacropping soils of Australia, 1217

on watermelon and pumpkin, in Tanzania, $768 \mathrm{~N}$

Dietzgen, R. G., 1109

Difeo, L. V., 882N

Diffie, S., 1520

Dillard, H. R., 1028N

Ding, M., 357N

Dinolfo, M. I., 496N

Dioscorea spp. (yam), Yam mild mosaic virus in, in China, $1320 \mathrm{~N}$

Diospyros kaki (sweet persimmon), Zygophiala wisconsinensis on, in Korea, 616N

Diplodia corticola on grape, in Spain, $1315 \mathrm{~N}$ on live oak, in Florida, 1027N

Diplodia olivarum, on carob, in Italy, $776 \mathrm{~N}$

Diplotaxis tenuifolia (rocket), Alternaria

japonica on, in Italy, $1316 \mathrm{~N}$

Dixon, L., 357N

Dixon, L. J., 770N, 772N

Dixon, W., $1589 \mathrm{~N}$
Djedatin, G., 441

Djurle, A., 1204

Dogmus-Lehtijärvi, H. T., 222N

Dolovac, N., 719

Domier, L. L., 945

DON. See Deoxynivalenol

Donahoo, R. S., $1586 \mathrm{~N}$

Dong, J., 777N, 871N

Dong, W., 325

Dong, X. L., 1316N

Dong, Z. Y., $1190 \mathrm{~N}$

Dorrance, A. E., 401

Dothiorella iberica, on avocado, in California 1465

Doucet, R., 70N

Douhan, G. W., 767N

Doukas, E., 666

Dowell, F. E., 554

Doyle, V. P., 618N

Dragon's wort. See Artemisia dracunculus

Dreaden, T. J., $1027 \mathrm{~N}, 1589 \mathrm{~N}$

Dreo, T., 70N

Dryad, yellow. See Dryas drummondii

Dryas drummondii (yellow dryad),

Colletotrichum acutatum on, in Switzerland, $1031 \mathrm{~N}$

Du, H. Z., $880 \mathrm{~N}, 1586 \mathrm{~N}$

du Toit, L. J., 1147

Duan, C. X., 872N

Duan, Y. B., 226N

Duféal, D., 359N

Duffy, M., 729

Dung, J. K. S., 285, 1147

Duveiller, E., 1204

Dyer, A. T., 1089, 1099

Eastern hemlock. See Tsuga canadensis

Ebelhar, S. A., 1318N

Echinacea pallida (coneflower), 16SrII-D subgroup phytoplasma associated with, 773N, cover photo: June

Echinochloa oryzicola (late watergrass), Exserohilum monoceras on, in Turkey, 497N

Eckstein, B., 363N

Efthimiou, K. E., 78N

Eggplant. See Solanum melongena

Eggplant mottled dwarf virus (EMDV), in Pittosporum tobira, in Spain, $75 \mathrm{~N}$

Eikemo, H., 279

Ekzayez, A. M., 76N

El Jarroudi, M., 384

Eleftherohorinos, I. G., 1322N

Elena, K., 223N, 777N

Eleocharis dulcis, Phoma bellidis on, in China, $1190 \mathrm{~N}$

Eleutherococcus senticosus, Alternaria

tenuissima on, in China, $493 \mathrm{~N}$

Elliott, M. L., 356N, 358N

Ellis, M. L., 401

Elmer, W. H., 960

Elsinö̈ ampelina, on grape, model to estimate amount of primary inoculum of, 1167

Embellisia hyacinthi, on Scilla peruviana, in California, 356N

EMDV. See Eggplant mottled dwarf virus

Enterobacter cloacae, on onion, in New York $1581 \mathrm{~N}$

Enterobacter mori, on mulberry, specific and sensitive detection of, 1070

Episomal viral sequences, discrimination from integrated viral sequences, 57

Erattaimuthu, S. R., 523

Erjavec, J., 70N

Erpelding, J. E., 523

Erper, I., 76N, 497N

Eruca sativa (rocket) Alternaria japonica on, in Italy, 1316N Fusarium equiseti on, in Italy, 1315N Erwinia spp. 
E. amylovora

on apple, loop-mediated isothermal amplification for rapid detection of, 423

on pear: kasugamycin for management of, 448; loop-mediated isothermal amplification for rapid detection of, 423

E. papayae-like bacterium, on papaya, $70 \mathrm{~N}$

E. tracheiphila

on muskmelon, delaying row covers for suppression of, 725

on pumpkin and watermelon, in New Mexico, $1583 \mathrm{~N}$

Erysiphe spp.

E. diffusa, on papaya, in Taiwan, $1188 \mathrm{~N}$

E. euonymi-japonici, on Euonymus

japonicus, in China, $611 \mathrm{~N}$

E. necator, on Vitis spp., variation within and among species for host resistance, 202

E. polygoni, on sugar beet, in Michigan, $494 \mathrm{~N}$

E. quercicola, on Ubame oak, in Korea, $77 \mathrm{~N}$ Escobar, R. E., 263

Eskalen, A., 770N, 1187N, 1189N, 1465

Eskandari, F. M., 907

Esker, P. D., 601, 1401, 1407

Eskridge, K. M., 554, 1370

Esterio, M., 683

Estévez, R., 683

Estragon. See Artemisia dracunculus

Etarock, B. F., 1583N

Eucomis vandermerwei (pineapple lily), Botrytis hyacinthi on, in California, $224 \mathrm{~N}$

Euonymus japonicus, Erysiphe euonymijaponici on, in China, $611 \mathrm{~N}$

Euphorbia pekinensis, Podosphaera euphorbiae-helioscopiae on, in China, 1314N, cover photo: October

Euphorbia pulcherrima (poinsettia),

Xanthomonas axonopodis pv. poinsettiicola

on, $70 \mathrm{~N}, 1187 \mathrm{~N}$, cover photo: January

European ash. See Fraxinus excelsior

Eustoma spp. (lisianthus)

Carnation mottle virus in, in Taiwan, $1036 \mathrm{~N}$

as indicator host for Iris yellow spot virus, 1520

Moroccan pepper virus in, in Iran, $1485 \mathrm{~N}$, cover photo: November

Eutypella spp.

on citrus, in California, $1187 \mathrm{~N}$

on grape, in Chile, $490 \mathrm{~N}$

Evans, E. A., 977

Evans, T. A., 71N

Exadaktylou, E., 79N, 872N

Exserohilum spp.

on Calathea picturata, in Taiwan, $1033 \mathrm{~N}$

on late watergrass, in Turkey, $497 \mathrm{~N}$

Faedda, R., 362N, 769N, 776N

Faghihi, M. M., 419

Fairweather, M. L., 494N

Fairy rings, identification and distribution of fungi associated with on golf putting greens, 1131

False brome grass, purple. See Brachypodium distachyon

Fan, G., 1314N

Fan, X. Y., 1070

Fang, Q., 357N

Farinon, O. M., 774N, 1476N

Faubert, H., 1584N

Faure, C., $1196 \mathrm{~N}$

FD phytoplasma. See Flavescence dorée phytoplasma

Fegan, M., 1109

Fellers, J. P., 183, 1516

Fenbuconazone, for Monilinia fructicola, 828

Feng, C., 876N
Feng, C. T., 1033N

Feng, J., 774N

Feng, Y.-G., 612N

Feng, Z.-K., 1483N

Fernandes, N. Gimenes-, 104

Fernandes-Acioli, N. A. N., 1196N

Fernández-Ortuño, D., 1482N

Ferreira, M. A. S. V., 793

Ferrin, D. M., 353N, 1192N

Fessehaie, A., 1420

Fetch, T., 1591N

Fiallo-Olivé, E., 1592N

Fichtner, E. J., 13

Finnegan, P. M., 1590N

Fir, Fraser. See Abies fraseri

Fischl, G., 1193N

Flavescence dorée (FD) phytoplasma, on grape, in Croatia, $353 \mathrm{~N}$

Flores, F. J., 1233

Florida torreya. See Torreya taxifolia

Fludioxonil, for Fusarium spp. on potato, resistance to, $228 \mathrm{~N}$

Fluopicolide, for Phytophthora capsici baseline sensitivity determination, 1414 wild type sensitivity and mutation analysis for resistance risk to, 1535

Focus, 3, 91, 231, 367, 503, 623, 783, 887, 1039, 1203, 1327, 1491

Fogle, D. G., 356N

Fonsah, E. G., 490N

Fonseca, M. E. N., 1196N, 1318N

Font, M. I., 75N

Fontenele, R. S., 1196N

Forbes, G., 1204

Forbes, G. A., 839

Formica, P. T., 1194N

Förster, H., 448

Fortnum, B. A., 835

Fraedrich, S. W., 612N, 1056, 1479N

Fragaria $\times$ ananassa (strawberry)

Botrytis cinerea on boscalid-resistant isolates, 1302 in South Carolina, 1482N

Macrophomina phaseolina on, in Argentina, $1477 \mathrm{~N}$

Phytophthora spp. on, in Japan, 1270

Pilidium concavum on, in Belgium, 1029N, cover photo: August

Strawberry necrotic shock virus in, in China, $1198 \mathrm{~N}$

Franceschini, A., 618N

Francisco, M., 292

Franklin, P., 358N

Fraser fir. See Abies fraseri

Fraxinella. See Dictamnus dasycarpus

Fraxinus excelsior (European ash),

Hymenoscyphus pseudoalbidus on, in

Belgium, 220N

Frayssinet, S., 882N

Frederick, R. D., 577

Frederick, Z. A., 1589N

Frederiksen, R., 523

Freier, J., 1584N

French, J., 871N

French, J. M., 1028N, 1029N

French-Monar, R. D., 73N, 1313N

Fu, F. H., 494N

Fu, L. L., 611N

$\mathrm{Fu}, \mathrm{Y} ., 880 \mathrm{~N}$

Fuchs, M., 735

Fuchsia spp., carlavirus in, in New Zealand, $1484 \mathrm{~N}$

Fuentes-Bueno, I., 1516

Fuga, C. A. G., 1588N

Fullerton, R. A., 70N

Fungicides

for Alternaria alternata, on pistachio, resistance to, 178

for Botrytis cinerea, in N. German small- fruit production, resistance against, 1263

for Cercospora zeae-maydis, on corn,

resistance to, 189

fluopicolide, for Phytophthora capsici baseline sensitivity determination, 1414 wild type sensitivity and mutation analysis for resistance risk to, 1535 for Fusarium spp., on wheat, 554

for Monilinia fructicola, sensitivity to, 821, 828

Penicillium expansum on apple, resistance and, $72 \mathrm{~N}$

for Phytophthora capsici, wild type sensitivity and mutation analysis for resistance risk to, 1535

for Phytophthora erythroseptica on potato, 691, 997

for Puccinia spp., on wheat and daylily, effect on urediniospore production, 325

for Pyrenophora tritici-repentis, on wheat, detection of QoI fungicide-resistant isolates, 1558

for Pythium spp. on geranium, dosage effect and resistance, 1233

for Raffaelea lauricola, on avocado and redbay, 977

resistance to in Monilinia fructicola, $497 \mathrm{~N}$

for Sclerotinia homoeocarpa on turfgrasses effects of dew removal and mowing frequency on performance o, 1427 resistance to, 51

for Sphaeropsis pyriputrescens on apple, 1075

for Venturia inaequalis on apple G143A mutation and QoI fungicide resistance, 927 resistance to multiple, 921 , cover photo: August

for Verticillium dahliae, colorimetric microtiter bioassay for sensitivity evaluation, 248

Funnell-Harris, D. L., 648

Fusarium spp.

in air and soil associated with sorghum fields, 648

on asparagus, replant soils, biochar

amendments and, 960

F. cerealis, on barley, in China, $774 \mathrm{~N}$

$F$. equiseti, on rocket, in Italy, $1315 \mathrm{~N}$

$F$. graminearum

on corn, in South Africa, 1153

on soybean, effect of seed treatments on disease under controlled conditions, 401

on wheat: corn residue as source of inoculum, 1458; grain harvesting strategies to minimize losses from, 1448; resistance to inital infection and spread by deoxynivalenol and nivalenol chemotypes of, 31

F. incarnatum, on walnut, from Japan, $1587 \mathrm{~N}$

F. lactis, on pepper, in Korea, $1476 \mathrm{~N}$

novel on Torreya taxifola, 633

F. oxysporum

on apple cactus, in Italy, $877 \mathrm{~N}$

f. sp. canariensis, on Canary Island date palm, 358N, $1192 \mathrm{~N}$

on chicory, in Italy, $496 \mathrm{~N}$

for control of Fusarium oxysporum $\mathrm{f}$. sp. cubense on banana, 951

f. sp. cubense, on banana, 951

on jade, in Italy, $1191 \mathrm{~N}$

f. sp. palmarum, on Canary Island date palm, 356N

f. sp. passiflorae, on passion flower, $1478 \mathrm{~N}$

on Philotheca myoporoides, in Italy, $877 \mathrm{~N}$ 
f. sp. radicis-cucumerinum, soil solarization, organic amendments and, 1116

f. sp. vasinfectum, on cotton, 967 on potato, fludioxonil-resistant, $228 \mathrm{~N}$

$F$. proliferatum

on blueberry, in Argentina, 1478N on chili pepper, in Trinidad, 1313N, cover photo: October on Gypsophila paniculata, in Korea, $220 \mathrm{~N}$

on soybean, in United States, 1316N

$F$. pseudograminearum, on wheat, and

Bipolaris sorokiniana, population

dynamics between using real-time qPCR, 1089

F. solani

on broomrape, in India, $75 \mathrm{~N}$

on olive, in Argentina, $1476 \mathrm{~N}$

on tarragon, in California, $768 \mathrm{~N}$

F. torulosum, on potato, in United States, $1194 \mathrm{~N}$

F. tricinctum, on wheat, in Argentina, 496N

$F$. verticillioides, on Rhodiola sachalinensis in China, $222 \mathrm{~N}$

$F$. virguliforme

quantification of in soil, 1420 on soybean, 242, 436

on wheat

distribution and prevalence in Montana, 1099

effects of integrating cultivar resistance and fungicide application, 554

Fusicladium oleagineum, on olive, 1139

Gachango, E., 228N, 1194N

Gadelseed, A. M. A., 1321N

Gadoury, D. M., 279

Gagnevin, L., 774N, 1312N

Gai, Y., 1031N, 1480N

Gajanandana, O., 1172

Gale, L. R., 31

Galperin, M., 874N

Gama, M. A. S., 793

Gamliel, A., 1116

Gandhi, K. J. K., 612N

Gao, B.-D., 219N, 1026N

Gao, J., 493N, 769N, 771N

Garbelotto, M., 619N

García, M. J., 1583N

García-Benavides, P., 361N

Garcia-Estrada, R. S., 1195N

García-Figueres, F., 874N

García-Jiménez, J., 803

Garibaldi, A., 76N, 224N, 225N, 496N, 873N,

$877 \mathrm{~N}, 878 \mathrm{~N}, 880 \mathrm{~N}, 1191 \mathrm{~N}, 1315 \mathrm{~N}, 1316 \mathrm{~N}$,

$1317 \mathrm{~N}, 1481 \mathrm{~N}$

Garlic. See Allium sativum

Garlic virus $X(\mathrm{GarV}-\mathrm{X})$, in garlic, in India, $1197 \mathrm{~N}$

Garrett, K. A., 1204

Garzón, C. D., 1233

Gaska, J. M., 1401

Gatsios, A. P., 78N

Gay, D. A., 1346

Gea, F. J., 1030N

Gehesquière, B., 1477N

Geijskes, R. J., 57

Geils, B. W., 494N

Gentiana macrophylla, Impatiens necrotic spot virus in, in China, 357N

Geranium, Pythium spp. on, mefenoxam and, dosage effect and resistance, 1233

Gerbera hybrida, Tomato spotted wilt virus in, in Serbia, $226 \mathrm{~N}$

Gerik, J. S., 967

Ghesquière, A., 441

Giayetto, A., 882N

Gibberella zeae. See Fusarium graminearum
Gibberellic acid, for management of Botrytis cinerea on grape, 269

Giblin-Davis, R. M., 1308

Gilardi, G., 496N, 1315N, 1316N

Gildow, F. E., 751, 945

Gill-Langarica, E. M., 778N

Giolitti, F., 771N

Girard, J-C. R., 357N

Gitaitis, R., 1520

Glasa, M., 38

Glassman, K. R., 469

Glaz, B., 640

Gleason, M. L., 368, 493N, 729, 1179

Gliocephalotrichum bulbilium, on cranberry, in New Jersey, 618N

Globodera rostochiensis (golden potato cyst nematode), on potato, in Bosnia and Herzegovina, 883N

Glomerella acutata, on chili pepper, in China, $219 \mathrm{~N}$

GLRaV-1. See Grapevine leafroll-associated virus 1

Glycine max, detection and discrimination of Puccinia polysora and Puccinia sorghi on, 624

Glycine max (soybean)

Bean pod mottle virus in, within-field temporal and spatial dynamics, in Spain, 126

Cercospora sojina on, in Virginia, $878 \mathrm{~N}$

Fusarium spp. on

$F$. graminearum, effect of seed treatments on disease under controlled conditions, 401

$F$. proliferatum, in United States, $1316 \mathrm{~N}$

$F$. virguliforme: effects of soil temperature and plant age at time of inoculation, 436; impacts of plant age on, 242

Macrophomina phaseolina on, seasonal progress of, 1159

Neocosmospora vasinfecta var. vasinfecta on, in China, $1031 \mathrm{~N}$

Phakopsora pachyrhizi on

characterizing resistance, 577

comparison of visual rust assessments and DNA levels in genotypes varying in resistance, 1007

crop monitoring, spore trapping, and aerobiological modeling for prediction of, 1346

dynamics in sequential plantings in

Nigeria, 43

effects of shade intensity and duration on, 485

effects of silicon applications on, 317

epidemiology in sentinel plots in Florida, 744

Phomopsis longicolla on, viral infection and, 530, cover photo: May

phytoplasma disease on, in Malawi and

Mozambique, $492 \mathrm{~N}$, cover photo: April

pigweed and waterhemp in, biological control of, 469

Glynn, N. C., 357N, 640

Glyphosate, for Rhizoctonia spp. on barley, preplant applications of, 304

Goates, B. J., 478

Goenaga, R., 1313N

Goldberg, N. P., 871N, 1028N, 1029N

Golden potato cyst nematode. See Globodera rostochiensis

Golino, D. A., 657

Golovinomyces spp.

G. ambrosiae, on giant ragweed, in Korea $1480 \mathrm{~N}$

G. biocellatus, on bergamot, in Korea, $1590 \mathrm{~N}$

G. cichoracearum on moth mullein, in Italy, $225 \mathrm{~N}$

on Ruth's golden aster, in Tennessee, $879 \mathrm{~N}$

on Symphyotrichum novi-belgii, in

Denmark, $228 \mathrm{~N}$

on zinnia, in Turkey, $1317 \mathrm{~N}$

Gong, L.-Z., 219N

Gongora-Canul, C. C., 242, 436

Gonzalez Segnana, L., 613N

Gonzalez-Franco, A. C., 778N

Gopal, D. Sai, 1476N

Gorbet, D. W., 263

Gossypium spp. (cotton)

Fusarium oxysporum $\mathrm{f}$. sp. vasinfectum on, efficacy of four soil treatments against, 967

reniform nematode on, Catenaria auxiliaris parasitizing, $490 \mathrm{~N}$

Goswami, R. S., 408

Gouk, C., 1109

Govers, J., 495N

Grabke, A., $772 \mathrm{~N}$

Grafting, citrus sudden death transmission and, 104

Graham, J. H., 725

Gramaje, D., 615N, 803, 1028N, 1040

Granata, G., 776N

Grand, L. F., 1131

Granke, L. L., 1080, 1358, 1392

Grape. See Vitis spp.

Grapefruit. See Citrus paradisi

Grapevine leafroll-associated viruses (GLRaV) in grape, in Washington state, $613 \mathrm{~N}$ Vitis spp. and hybrids as hosts of, 657

Grapevine viruses $A$ and $B$, Vitis spp. and hybrids as hosts of, 657

Grapevine yellow speckle viroid 1 (GYSVd-1), in grape, in New Zealand, 617N

Gray, M. E., 413, 616N

Gray, S. M., 1279

Green manures

Fusarium disease and, 1116

for Streptomyces turgidiscabies on potato, 1124

for Verticillium dahliae on potato, 568

Greene, I. D., 224N

Greeneria uvicola, on grape, detection and monitoring by real-time PCR, 298

Greenwald, C., 523

Greer, L. A., 298

Gregory, N. F., 71N

Gregos, J., 847

Gremillion, S. K., 263

Griffey, C. A., 19

Groenewald, J. Z., 876N

Gross, D. C., 1542

Grosso, S., 772N

Groves, R. L., 232

Grubišic, D., 883N

Grünwald, N. J., 337

Gu, H. F., 73N

Gu, Y. H., 73N

Gu Y. H., 73N

Gualandi, R. J. Jr.,, 1191N

Guarnaccia, V., 877N, 1194N, 1588N

Guatimosim, E., 1588N

Gudmestad, N. C., 691, 997, 1558

Gullino, M. L., 76N, 225N, 496N, 873N, 877N, $878 \mathrm{~N}, 880 \mathrm{~N}, 1191 \mathrm{~N}, 1315 \mathrm{~N}, 1316 \mathrm{~N}, 1317 \mathrm{~N}$, $1481 \mathrm{~N}$

Guo, L.-Y., 1284

Guo, W. X., 776N

Gurung, S., 582

Gwandu, C., 224N

Gwinn, K. D., 1191N, 1195N, 1585N

Gymnosporangium nelsonii, on juneberry, in Michigan, $770 \mathrm{~N}$

Gynura bicolor, Phytophthora drechsleri on, in Taiwan, 874N 
Gypsophila paniculata, Fusarium proliferatum on, in Korea, 220N

GYSVd-1. See Grapevine yellow speckle viroid 1

Haematonectria haematococca, on citrus, in

Philippines, 1590N

Hahn, J. H., 589

Hahn, M., 1302

Halbert, S. E., $1475 \mathrm{~N}$

Hallett, S. G., 469

Halmschlager, E., 222N

Haluška, I., 353N

Hambleton, S., 1346

Hamed, A. A., $1592 \mathrm{~N}$

Hamed, K., 1321N

Hammond, R., 1482N

Han, K. S., 1590N

Hansen, E. M., 337

Hansen, J. M., 582

Hansen, M. A., 71N

Hanson, B. D., 967

Hanson, L., 228N, 1194N

Hanson, L. E., 494N

Hanson, S. F., 871N

Hao, J. J., 1535

Haq, M.-I., 1581N

Harding, R. M., 57

Hariri, D., $70 \mathrm{~N}$

Harmon, C. L., 485

Harmon, P. F., 485, 515

Harper, S. J., 617N, 775N

Harrington, T. C., 1056, 1474N, 1478N, 1479N

Harris, R. S. III, $1192 \mathrm{~N}$

Harrison, N., 256

Harshman, D., 74N

Hartman, G. L., 43, 343, 577, 1007, 1034N

Hartman, J. R., 1179

Hasanzadeh, H., 419

Hashizume, K., 1124

Hassani-Mehraban, A., 1485N

Haudenshield, J. S., 343, 1034N

Hausbeck, M. K., 1080, 1358, 1392, 1535

Havis, N. D., 595

Hawkins, T. S., 1056

Hay, F. S., $1478 \mathrm{~N}$

Hayes, R. J., 784

Haynes, J. L., 361N

He, G., $879 \mathrm{~N}$

He, H.-P., 219N

He, P., 776N

Headrick, J. M., 1492

Hébrard, E., 1063

Hed, B., 269

Helianthus annuus (sunflower), Macrophomina phaseolina on

in Illinois, $1318 \mathrm{~N}$

in Turkey, $223 \mathrm{~N}$

Helms, T. C., 1239

Helson, M., 220N

Hemionitis arifolia, Myrothecium roridum on, in China, 1030N

Hemlock, eastern. See Tsuga canadensis

Herdina, 1217

Hernández, E., 497N, 1482N

Hernandez Nopsa, J., 554

Herpotrichia juniperi, on Lebanon cedar, in

Turkey, 222N, cover photo: February

Herrero, M. L., 355N

Herselman, L., 611N, 1188N

Heterodera spp. (cyst nematodes)

$H$. avenae (cereal cyst nematode), on wheat, foliarly applied spirotetramat and, 983

H. glycines (soybean cyst nematode), on Phaseolus vulgaris (bean), reproduction over multiple generations, 1239

$H$. ripae, on common nettle, in Spain, $883 \mathrm{~N}$

Heungens, K., 1029N, 1477N

Hexinia polydichotoma, Leveillula lactucae-

serriolae on, in China, $879 \mathrm{~N}$
Higgins, R., 1370

Hilber-Bodmer, M., 497N

Hill, C. B., 1007

Himananto, O., 1172

Hishimonus phycitis, and Candidatus

Phytoplasma aurantifolia on lime, 419

Ho, W. C., $1033 \mathrm{~N}$

Hoang, A. T., 1063

Hodson, D., 1188N, 1204

Hodson, D. P., 1591N

Hoepting, C. A., 735

Hoffmann, L., 384

Hogg, A. C., 1089, 1099

Holmes, E. C., 751

Honeycutt, C. W., 568

Honeycutt, E., 358N

Hong, N., 1319N, 1483N

Hong, S. K., 1476N

Hongprayoon, R., 1172

Hop stunt viroid (HSVd)

in cucumber, $615 \mathrm{~N}$

in grape, in New Zealand, $617 \mathrm{~N}$

Hordeum vulgare (barley)

cultivar effects and expression of induced resistance in, 595

Fusarium cerealis on, in China, 774N

Polymyxa graminis f. sp. temperata as vector of soilborne viruses of, in Czech Republic, 353N

Pyrenophora teres on, genetic

characterization of resistance genes, 19

Rhizoctonia spp. on, preplant glyphosate applications for management of, 304

Horevaj, P., 31

Horlock, C., 1109

Horst, W. J., 394

Horváth, A., 1034N

Host resistance against Erysiphe necator, on grape, 202 against Fusarium spp., on wheat, 31, 554 against leaf spots, in peanut, 263 against Microdochium spp. and Typhula spp., on turfgrasses, mow height and, 839 against Phakopsora pachyrhizi, on soybean, 577

against Puccinia graminis f. sp. tritici in A-genome diploid wheat relatives, 941 race TTKSK (Ug99), 762

against Pyrenophora teres, in barley, 19

against Rhizoctonia solani, on rice, quantification using detached tiller test under controlled conditions, 1507 against Sclerotinia sclerotiorum on soybean, variations in isolates from multisite resistance screening locations, 1370

of sweet corn hybrids in disease nurseries, 1492

against Xanthomonas spp.

$\mathrm{X}$. campestris pv. campestris, on

Brassica napus, 292

X. oryzae pv. oryzae on, on rice, 441

$\mathrm{X}$. translucens pv. undulosa, on wheat, identifying new sources of, 582 against Xylella fastidiosa, on almond, 166

Hou, L. Q., 773N

Houttuynia cordata, Alternaria alternata on, in China, 359N

Howard, R. J., 873N

Hrudová, E., 79N

Hsiang, T., 359N, 1190N, 1378

Hsu, C. L., 735

HSVd. See Hop stunt viroid

$\mathrm{Hu}$, C. J., $1197 \mathrm{~N}$

$\mathrm{Hu}$, D. F., $1591 \mathrm{~N}$

Hu, M. J., 225N, 772N

$\mathrm{Hu}, \mathrm{X} . \mathrm{P} ., 1591 \mathrm{~N}$

Hu, Z.-Z., $1483 \mathrm{~N}$

Huang, C.-H., 362N, 461

Huang, J., 359N, 1190N, 1378, 1483N
Huang, J. H., 1030N

Huang, X., 1318N

Huangfu, W. G., 73N

Hubert, J., 359N

Huff, S., 1191N

Hughes, M., 1588N

Hughes, M. E., 935

Hulbert, S. H., 304

Hung, S. C., $1581 \mathrm{~N}$

Hussain, K., 1581N

Hussnain, S.-Z., 1581N

Hutmacher, R. B., 967

Hwang, D. J., 589

Hyacinths. See Scilla spp.

Hyder, N., 492N

Hymenoscyphus pseudoalbidus, on Fraxinus excelsior, in Belgium, $220 \mathrm{~N}$

Idris, A. M., 120

Ikegami, M., $1485 \mathrm{~N}$

Imadacloprid, Xanthomonas citri subsp. citri on grapefruit and, 725

Impatiens necrotic spot virus (INSV), in

Gentiana macrophylla, in China, 357N

Impatiens walleriana, Plasmopara obducens on, in Serbia, $491 \mathrm{~N}$

Imtiaz, M., $1192 \mathrm{~N}$

Inácio, C. A., $1318 \mathrm{~N}$

Inch, S. A., 977

Indian mustard. See Brassica juncea

Indiangrass. See Sorghastrum nutan

Induced systemic response (ISR), cultivar

effects on expression of in barley, 595

Inghelbrecht, S., 1477N

Insecticides, for cereal cyst nematode on wheat, 983

INSV. See Impatiens necrotic spot virus

Integrated viral sequences, discrimination from episomal viral sequences, 57

Ioos, R., 359N

Iotti, J., 359N

Ipomea batatas (sweetpotato)

Sweet potato chlorotic stunt virus in, in China, 356N

Sweet potato leaf curl virus in, 1385

Sweet potato symptomless virus 1 and Sweet potato virus $A$ in, in Tanzania, $224 \mathrm{~N}$

Irfan, A., $1581 \mathrm{~N}$

Iris yellow spot virus (IYSV)

lisianthus as indicator host for, 1520

in onion

in Kenya and Uganda, 1195N in New York, 735

in relatives of onion, $1319 \mathrm{~N}$

Irrigation water, Phytophthora capsici in, 1358

Isard, S. A., 1346

Ismail, I., 76N

Ivanovic, M., 368

Ivors, K. L., 537

IYSV. See Iris yellow spot virus

Izadpanah, K., 419

Jackson, M. A., 24

Jackson, P., 1581N

Jackson, T. A., 73N

Jacobsen, B. J., 1089, 1099

Jadão, A. S., 1021

Jade. See Crassula ovata

Jain, R. K., 1197N

Jalapeño Pepper, Beet severe curly top virus in, in Mexico, $778 \mathrm{~N}$

James, A. P., 57

James, T. Y., 358N

Jan, F.-J., 354N, 362N

Jankovics, T., 719

Japanese apricot. See Prunus mume

Japanese walnut. See Juglans ailantifolia

Jarret, R. L., 1385

Jeffers, S. N., 811 
Jellywort. See Mesona chinensis

Jensen, B. D., 768N

Jesus Junior, W. C., 104

Jeyaprakash, A., 1475N

Ji, C., $1031 \mathrm{~N}, 1480 \mathrm{~N}$

Ji, P., 490N

Jiang, D. M., 494N

Jiang, W. T., 1314N

Jiang, Z.-L., 357N

Jicama. See Pachyrhizus erosus

Jie, L. S., 1033N

Jijakli, M. H., 137, 311

Jiménez-Díaz, R. M., 143, 860

Jiménez-Fernández, D., 860

Jin, G. L., 1070

Jin, Y., 762, 941

Jin, Z., 523

Jirak-Peterson, J. C., 601

Joa, J. H., 1311N

Johnson, C., 1480N

Johnson, D. A., 285, 1147

Johnson, J., 1056

Johnson, K. B., 423

Johnson, K. L., 697

Jones, D. C., 4

Jones, J. B., 697

Jones, S. J., 1478N

Jones, S. S., 92

Jongen, C., 495N

Joshi, S., 1197N

Jovic, J., 226N, 491N, 1035N

Józsa, A., 1193N

Juglans ailantifolia (Japanese walnut), walnut witches'-broom phytoplasma on, in Iowa, $1474 \mathrm{~N}$

Juglans regia (walnut)

Fusarium incarnatum on, from Japan, 1587N

Pantoea agglomerans on, in China, 773N

Xanthomonas arboricola pv. juglandis on, 1565

Juneberry. See Amelanchier alnifolia

Jung, G., 51

Jurkovic, D., $612 \mathrm{~N}$

Juzwik, J., 888

Kageyama, K., 1270

Kalha, C. S., 1482N, 1587N

Kamenova, I., 1320N

Kaminski, J. E., 1427, 1433

Kammerer, S. J., 515

Kang, J. M., 611N

Kang, M. J., 589

Kang, Y. B., 226N

Karaoglanidis, G. S., 178, 666, 1302

Karasev, A. V., 778N

Karkashian, J., 901

Karthikeyan, G., 613N

Kassanelly, D., 1586N

Kasugamycin, for control of Erwinia amylovora on pear, 448

Kasun, G. W., 166

Katan, J., 1116

Katis, N. I., 78N, 120

Katoch, A., 1584N

Kaur, P., 712

Kaur, R., 353N

Kausar, H., 495N

Kawchuk, L. M., 873N

Kaya Altop, E., 497N

Keinath, A. P., 1414

Keller, M. D., 1458

Kelly O'Brien, G., 744

Kentucky bluegrass. See Poa pratensis

Kenworthy, K. E., 1308

Kenyon, L., 1197N

Ketta, H., 353N

Khan, A., $1582 \mathrm{~N}$

Khan, A. J., 360N

Khan, T. N., $1590 \mathrm{~N}$
Khoshgoftarmanesh, A. H., 455

Khozeini, F., 882N

Kikuyugrass. See Pennisetum clandestinum

Kim, C. J., 77N

Kim, C. K., 589

Kim, H. B. Lee C. J., 220N

Kim, J., 616N, 1585N

Kim, J.-G., 1582N

Kim, W. G., 1476N

Kim, Y. H., 358N

Kim, Y. K., 72N, 1075

Kirk, S. A., 13

Kirk, W., 228N, 1194N

Kirkpatrick, B. C., 158, 166, 173

Kirschbaum, D. S., 1477N

Kiss, L., 361N, 719

Kitajima, E., $771 \mathrm{~N}$

Kitajima, E. W., 104, 613N

Kiwifruit. See Actinidia chinensis

Klaassen, V. A., 657

Klein, E., 1116

Klejdysz, T., 1475N

Klosterman, S. J., 1224

Ko, Y., 78N

Koehler, G., 1179

Koike, S. T., 71N, 768N, 876N

Kolmer, J. A., 935, 1032N

Kondo, N., 1124

Koné, D., 490N

Kong, F.-F., 219N

Konstantinou, S., 666

Korus, K. A., 73N

Kositratana, W., 1172

Kousik, C. S., 360N, 1414, 1586N

Krause-Sakate, R., 227N

Krawczyk, K., 1475N

Krid, S., 770N

Kristiansen, K., 228N

Križanac, I., 353N

Krizbai, L., 363N

Krstic, B., 226N, 491N, 719, 882N, 1035N

Kruse, J. K., 1308

Krysinska-Kaczmarek, M., 1217

Kuang, R. F., 1319N

Kudzu. See Pueraria montana var. lobata

Kuhlmann, M., 945

Kullaya, A., 224N

Kumari, S., $1321 \mathrm{~N}$

Kumari, S. G., 76N

Kumpoosiri, M., 1172

Kwon, J.-H., 616N, 1585N

Lababidi, S., $1321 \mathrm{~N}$

Lablab purpureus, Bean common mosaic virus in, in India, $881 \mathrm{~N}$

Lackermann, K. V., 1401, 1407

Lacorte, C., $1196 \mathrm{~N}$

Lactuca sativa (lettuce), Verticillium dahliae on, 784, cover photo: July

Lahlali, R., 311

Lahoz, E., 611N

Lamichhane, J. R., 221N

LaMondia, J. A., 496N

LAMP. See Loop-mediated isothermal amplification

Lamppa, R. S., 408

Lamprecht, S. C., 1153

Landa, B. B., 143, 860

Landsat 5 Thematic Mapper (TM) images, for remote sensing of wheat infected by Wheat streak mosaic virus, 4

Landschoot, P. J., 1427

Larkin, R. P., 568

Larsen, M. M., 337

Lasiodiplodia theobromae, on pomelo, in China, $1190 \mathrm{~N}$

Laski, P. J., 767N, 777N, 871N

Lasmenia sp., on rambutan, in Puerto Rico, $1313 \mathrm{~N}$
LATEBLIGHT simulation model, assessing under Nicaraguan conditions, 839

Latorre, B. A., 490N, 492N, 1032N, 1193N

Lava Kumar, P., 492N, 618N

Lavandula angustifolia (lavender),

Phytophthora palmivora on, in Turkey, 1035N

Lawrence, K. S., 490N

Layton, C. N., $1587 \mathrm{~N}$

LChD. See Little cherry disease

Le, T., 697

Leandro, L. F., 1316N

Leandro, L. F. S., 242, 436, 1420

Lebanon cedar. See Cedrus libani

Lebas, B. S. M., 775N

Lebeda, A., $878 \mathrm{~N}$

Lecoq, H., 153, 220N

Leduc, A., $1311 \mathrm{~N}$

Lee, H. B., 77N

Lee, K. -H., 77N

Lee, L. M., $1197 \mathrm{~N}$

Lee, Y. H., 220N, $1585 \mathrm{~N}$

Lee, Y. K., $1476 \mathrm{~N}$

Lefebvre, A., 1167

Lehtijärvi, A., 222N

Leifsonia xyli subsp. xyli, on sugarcane, in Pakistan, $1581 \mathrm{~N}$

Leininger, T. D., 1056

Leipotylenchus abulbosus, first report of in Iran, $882 \mathrm{~N}$

Leisova-Svobodova, L., 220N, 1321N

Lema, M., 292

Lemes, E. M., 317

Lemmetty, A., $615 \mathrm{~N}$

Lemon, Volkamer. See Citrus volkameriana

Lenardon, S., $771 \mathrm{~N}$

Leng, P. S., 1314N

Lentisk. See Pistacia lentiscus

León, M., 803

Leon-Felix, J., 1195N

Lepidium latifolium (pepperweed), Albugo candida on, in California, $876 \mathrm{~N}$

Lepoivre, P., 137

Leptosphaeria maculans, on canola, in Oklahoma, 614N

Leroch, M., 1302

Lesniak, K. E., 927

Lettuce. See Lactuca sativa

Leveillula lactucae-serriolae, on Hexinia

polydichotoma, in China, $879 \mathrm{~N}$

Levy, J., 1542

Levy, L., 614N

Lewis, R. S., 1443

Lewis, S. A., 835

Lewis Ivey, M. L., 1026N, 1584N

Li, B. H., $1316 \mathrm{~N}$

Li, B.-Q., 63

Li, C. W., 611N

Li, F., 1484N

Li, G., 1378

Li, G. F., 1316N

Li, H. J., $872 \mathrm{~N}$

Li, L., $1198 \mathrm{~N}$

Li, M., 1270

Li, Q., 359N

Li, R., 1484N

Li, S., $357 \mathrm{~N}$

Li, S. F., 494N, 1320N

Li, S. S., $1190 \mathrm{~N}$

Li, W.-H., 612N

Li, X., 485, 1482N, 1592N

Li, X. P., $1481 \mathrm{~N}$

Li, X.-H., 219N, 616N

Li, Y., 222N, 1314N

Li, Y. P., $1590 \mathrm{~N}$

Li, Z., $1320 \mathrm{~N}$

Liao, J. Y., 617N

Liefting, L. W., 617N, 1484N

Lily

Botrytis hyacinthi on, in California, 224N 
Puccinia hemerocallidis on, effect of postsymptom application of fungicides on urediniospore production by, 325

Puccinia thaliae on, in Louisiana, 353N

Lim, C. K., 589

Lima bean. See Phaseolus lunatus

Lime. See Citrus spp.

Lin, B.-S., $1483 \mathrm{~N}$

Lin, H., $1026 \mathrm{~N}$

Lin, J. T., $1190 \mathrm{~N}$

Lin, Y., $771 \mathrm{~N}$

Linaldeddu, B. T., 618N

Lindera melissifolia (pondberry), Raffaelea lauricola on, 1056

Ling, K. S., 1385

Ling, K.-S., 1026N, 1035N

Liriope muscari (lilyturf), spiral nematode on, in United States, 74N

Lisianthus. See Eustoma spp.

Litsea aestivalis (pondspice), Raffaelea lauricola on, $1056,1588 \mathrm{~N}$

Litt, A., 618N

Little, C. R., 853

Little cherry disease (LChD), in Prunus spp., in Czech Republic, 1197N

Little cherry virus 2, in Prunus spp., in China, $1484 \mathrm{~N}$

Liu, A. Q., 494N

Liu, B., $1480 \mathrm{~N}$

Liu, C. W., 78N

Liu, H. L., $874 \mathrm{~N}$

Liu, H. X., 773N

Liu, J. F., 222N

Liu, L. J., $1318 \mathrm{~N}$

Liu, Q., 222N

Liu, R., 431

Liu, S. Y., 1314N

Liu, T., $1314 \mathrm{~N}$

Liu, X., $773 \mathrm{~N}$

Liu, X. L., 225N, 1481N, 1535

Liu, Y., 611N

Live oak. See Quercus virginiana

Lizotte, E. M., $770 \mathrm{~N}$

Long, D. L., 935

Long, J. Y., 871N

Loop-mediated isothermal amplification

(LAMP), for detection of Erwinia amylovora on apple and pear, 423

Lopera, C., $875 \mathrm{~N}$

López, M. M., 1328, 1583N

Lopez-Nicora, H. D., 413

López-Robles, J., 883N

Lorè, A., $76 \mathrm{~N}$

Lore, J. S., 1507

Los, L., $1589 \mathrm{~N}$

Lou, M. M., 1070

Louws, F. J., $1480 \mathrm{~N}$

Lr21 gene, Puccinia triticina on wheat and, $1032 \mathrm{~N}$

Lu, B., $771 \mathrm{~N}$

Lu, J. P., 354N, 362N

Lu, X. H., 1535

Luc, J. E., 1308

Ludvíková, H., 1197N

Lunaria annua, Albugo candida on, 72N

Lund, O. S., $881 \mathrm{~N}$

Luo, C. X., $225 \mathrm{~N}, 772 \mathrm{~N}$

Luo, M., $1190 \mathrm{~N}$

Luo, Y., 178, 821

Luxananil, P., 1172

Lv, M. F., 879N

Lv, R., 359N, $1190 \mathrm{~N}$

Lycopersicon esculentum. See Solanum

lycopersicum (tomato)

Lyngs Jørgensen, H. J., 228N

M. Bové, J., 104

M. Tamò, $492 \mathrm{~N}$

Ma, X., 1584N
Ma, X. M., 611N

MacDonald, W. L., 888

Mackowiak, C. L., 317

Macrophomina phaseolina on mungbean, in China, $872 \mathrm{~N}$

on soybean, seasonal progress of, 1159 on strawberry, in Argentina, 1477N on sunflower in Illinois, $1318 \mathrm{~N}$ in Turkey, 223N

Madagascar periwinkle. See Catharanthus roseus

Madariaga-Navarrete, A., 775N

Madden, L. V., 1448

Maddux, L. D., 478

Madeiras, A., 1179

Maeda, M., 1124

Maes, M., 1029N

Maffia, L. A., 1479N

Magill, C. W., 523

Magnano di San Lio, G., 769N

Mahmoud, A., 223N

Mahtour, A., 384

Mahuku, G., 1204

Malabar spinach. See Basella alba

Malhotra, R. S., 1192N

Malus spp. (apple)

M. domestica

Erwinia amylovora on, loop-mediated isothermal amplification for rapid detection of, 423

Monilinia fructicola on, in Germany, $772 \mathrm{~N}$

Penicillium expansum on: in Greece, 666; pyrimethanil resistance and, 72N Penicillium griseofulvum on, in Italy, $76 \mathrm{~N}$

postharvest fruit rots of in Greece, 666 sooty blotch and flyspeck on, variability among forecast models for, 1179

Sphaeropsis pyriputrescens on, post-harvest fungicides for control of, 1075

Venturia inaequalis on

QoI fungicide resistance, G143A mutation and, 927

resistance to multiple fungicides, 921 , cover photo: August

Mandevilla splendens, Ralstonia solanacearum on, in United States, 614N

Mang, S. M., 72N

Mangifera indica (mango)

Colletotrichum gloeosporioides on, borate for control of, 63

Xanthomonas citri pv. mangiferaeindicae on in Burkina Faso, 1312N

in Ghana, 774N

Mani, C., 1582N

Mansilla, J. P., 776N, 1583N

Mansilla Vázquez, J. P., 221N, 1315N

Marais, A., 1196N

Marais, C., 363N

Maraite, H., 384

Marcel, T. C., 1339

Marchi, G., 74N

Marcinkowska, J., 493N

Margaria, P., 882N

Mariano, R. L. R., 793

Marie-Jeanne, V., 70N

Marigold. See Calendula officinalis

Markoglou, A. N., 666

Marois, J. J., 317, 744

Marquez-Villavicencio, M. D. P., 232

Marshall, J. M., 983

Martin, F. N., 337

Martin, L., 361N, 876N

Martin, M. T., 361N, 876N

Martin, T. J., 183

Martinka, M. J., 1401

Marubayashi, J. M., 227N
Maruthachalam, K., 1224

Maruthasalam, S., 78N

Masiri, J., 331

Mason, G., 772N

Massawe, A., 768N

Matanguihan, J. B., 92

Mathieu, T., 441

Matias, J., 1565

Mauzey, S. J., 71N

Maxwell, D. P., 901

May-De Mio, L. L., 821

Mayfield, A. E., 612N

Mayfield, A. E. III, $1588 \mathrm{~N}$

Mayr, U., 368

Mazzarella, R., 195

Mbanzibwa, D. R., 224N

Mbofung, G. C. Y., 1420

McBeath, J. H., 767N, 777N, 871N

McDonald, M. R., 504

McDonald, V., 1189N, 1465

McGrath, J. M., 494N

McGrath, M. T., 1028N

McKay, A., 1217

McLane, H., 619N

McManus, P. S., 368

McRoberts, N., 504

McSorley, R., 1308

Meadows, I. M., 811

Mech, A. M., 612N

Medicago sativa (alfalfa)

rhabdovirus infecting, in Argentina, 771N

Verticillium nigrescens on, in China, 1591N

Medina, E., $875 \mathrm{~N}$

Mefenoxam

for Phytophthora erythroseptica on potato, 691, 997

for Pythium spp. on geranium, dosage effect and resistance, 1233

Meinhardt, S. W., 1558

Mekete, T., 413

Melaleuca quinquenervia (paperbark), Puccinia psidii on, in California, $1314 \mathrm{~N}$

Meletti, L. M. M., 1021

Mello, A. F. S., 1279

Mello, A. P. O. A., 613N, 1021

Meloidogyne arenaria (root-knot nematode),

real-time PCR for identification of, 835

Melon. See Citrullus spp.; Cucumis spp.

Men, X., $771 \mathrm{~N}$

Mendes, B. M. J., 1021

Meng, J., 1320N

Mengistu, A., 1159

Mennan, H., 497N

Menzel, W., 1321N

Mersha, Z., $880 \mathrm{~N}$

Merz, U., $1033 \mathrm{~N}$

Mesona chinensis (jellywort), Ralstonia solanacearum on, in China, $222 \mathrm{~N}$

Metam-sodium, Fusarium oxysporum $\mathrm{f}$. sp. vasinfectum on cotton and, 967

Methyl benzimidazole carbamates, resistance to in Monilinia fructicola, $497 \mathrm{~N}$

Meyer, M. M., 173

Meyer, W. A., 1547

Michailides, T. J., 178, 821

Michel, V. V., 1031N

Michener, P. M., 1492

Microcyclosporella mali, on plum, in Poland, $493 \mathrm{~N}$

Microdochium spp., on fescue and bentgrass, closely mown, 839

Microsphaeropsis amaranthi, for control of

pigweed and waterhemp in pumpkin and

soybean, 469

Mikec, I., 353N

Miklic-Lautar, I., 70N

Miles, M. R., 577

Miles, T. D., 614N, 768N, 1187N

Milicevic, T., 883N 
Miller, G. L., 1131

Miller, S. A., 1026N, 1584N

Milus, E. A., 31

Milusheva, S., 1320N

Minas, I. S., 666

Minnis, A. M., $772 \mathrm{~N}$

Minno, M. C., $1588 \mathrm{~N}$

Minsavage, G. V., 697

Mior Ahmad, Z. A., 491N

Mirabolfathy, M., 876N

Mirik, M., 4

Mirzaee-Qomi, M., 882N

Mirzwa-Mróz, E., 493N

Miscanthus $\times$ giganteus, plant-parasitic

nematodes as potential pathogens of, 413

Miscanthus sinensis, Pythium sylvaticum on, in Illinois, $616 \mathrm{~N}$

Mituti, T., 227N

Mizutani, T., $1485 \mathrm{~N}$

Mo, X., $880 \mathrm{~N}$

Mohaghegh, P., 455

Mohammadi, H., 1034N

Molineros, J. E., 1233

Mollov, D., 614N

Monarda didyma (bergamot), Golovinomyces biocellatus on, in Korea, 1590N

Mondal, K. K., 1582N

Monilinia spp.

M. fructicola

on apple, in Germany, $772 \mathrm{~N}$

methyl benzimidazole carbamateresistant, $497 \mathrm{~N}$

on peach, in China, $225 \mathrm{~N}$

sensitivity to fenbuconazole and propiconazole, 828

sensitivity to tebuconazole, azoxystrobin, and thiophanate-methyl, 821

M. laxa, on Prunus spp., in New York,

Rhode Island, and Massachusetts, $1584 \mathrm{~N}$

on Prunus spp., in China, population structure of, 1284

Monteiro-Hara, A. C. B. A., 1021

Monterey cypress. See Cupressus macrocarpa

Montes, N., 523

Montes-Borrego, M., 143, 860

Montesinos, E., 1565

Montón, C., 874N

Moorman, G. W., 1233

Mora, F., 1482N

Moraes, M. G., 354N

Moragrega, C., 1565

Moral, J., 770N, 1139

Mora-Uma, F., 497N

Moreno, M. V., 496N

Morgado, F. G. A., 1318N

Morinda citrifolia (noni), Mucor circinelloides on, in Hawaii, 360N

Moriones, E., $1592 \mathrm{~N}$

Mørk, E. K., $228 \mathrm{~N}$

Moroccan pepper virus (MPV), in lisianthus, in Iran, $1485 \mathrm{~N}$, cover photo: November

Morus alba (mulberry), Enterobacter mori on, specific and sensitive detection of, 1070

Moth mullein. See Verbascum blattaria

Mount, L. L., 633

Moura, M. F., 227N

Moy, M., 1547

Moya-Elizondo, E. A., 1089, 1099

MPV. See Moroccan pepper virus

Msallem, M., 770N

Mucor circinelloides, on noni, in Hawaii, 360N

Mudgett, M. B., 1582N

Mughal, S.-M., $1581 \mathrm{~N}$

Mukhina, Z., $1586 \mathrm{~N}$

Mukoyi, F., 1188N

Mulberry. See Morus alba

Mulberry, paper. See Broussonetia papyrifera

Mulima, E., $1188 \mathrm{~N}$

Mullinix, B. G., 263
Mullis, S. W., 1520

Mun, H. Y., 77N, 220N

Mungbean. See Vigna radiata

Munkvold, G. P., 530, 1316N

Muñoz, G., 683

Muñoz-Ledesma, F. J., 143

Munster, M., $1480 \mathrm{~N}$

Murphy, J. A., 78N

Murphy, J. F., 331

Murphy, K. M., 92

Musa spp. (banana)

Fusarium oxysporum f. sp. cubense on, nonpathogenic Fusarium oxysporum and Pseudomonas fluorescens for control of, 951

Mycosphaerella fijiensis on, on Martinique Island, 359N

Rhizoctonia anastomosis group $\mathrm{F}$ on, $490 \mathrm{~N}$

Mushroom, king oyster. See Pleurotus eryngii

Muskmelon. See Cucumis melo

Mustard. See Brassica chinensis (field mustard);

Brassica juncea (Indian mustard); Sinapis arvensis (wild mustard)

Mutari, B., $1188 \mathrm{~N}$

Muthomi, J. W., 1195N

Mycosphaerella spp.

M. fijiensis, on banana, on Martinique Island, 359N

M. graminicola, on wheat, PROCULTURE model for, 384

M. pini, on Scots pine, in Norway, $875 \mathrm{~N}$

Myers, M. E., 725

Myrothecium roridum, on Hemionitis arifolia, in China, 1030N

Myung, I.-S., 1311N

Myzus persicae, Potato virus $Y$ strain transmission and, 1279

Nagata, T., 104

Nagy, G., 1034N

Nagy, Z. Á., 1193N

Naidoo, S., 767N

Naidu, R. A., 613N

Najar, A., $1321 \mathrm{~N}$

Nankam, C., 1492

Narla, R. D., $1195 \mathrm{~N}$

Narváez, D. F., 744

Narvaez, M., 256

Nasu, E. G. C., 1194N

National Fire and Fire Surrogate Study,

Phytophthora cinnamomi and, 811

Natsuaki, K. T., 1485N

Nault, B. A., 735

Nava-Diaz, C., $775 \mathrm{~N}$

Navarro, M. J., 1030N

Navas-Castillo, J., 1592N

Navas-Cortés, J. A., 860

Nawaz, K., 1581N

Nazerian, E., 491N, 1474N

Ndjiondjop, M.-N., 441

Negussie, T. G., $611 \mathrm{~N}$

Nejat, N., 1312N

Nelson, A., 1204

Nelson, B. D., 1239

Nematodes on bean, reproduction over multiple generations, 1239

on cotton, Catenaria auxiliaris parasitizing, $490 \mathrm{~N}$

on lilyturf, in United States, 74N

as pathogens of Miscanthus $\times$ giganteus and Panicum virgatum used for biofuels, 413 on Pinus pinaster, in Spain, $776 \mathrm{~N}$

on potato, in Bosnia and Herzegovina, 883N real-time PCR for identification of, 835 on wheat, foliarly applied spirotetramat and, 983

Neocosmospora vasinfecta on peanut, in China, $1480 \mathrm{~N}$ on soybean, in China, $1031 \mathrm{~N}$

Neofusicoccum spp.

on avocado, in California, 1465

on citrus, in California, $770 \mathrm{~N}$

on grape

in Chile, $1032 \mathrm{~N}$

in Spain, $876 \mathrm{~N}$

on hybrid rhododendrons, in Spain, $221 \mathrm{~N}$

$N$. mediterraneum, on grape, in Spain,

$1315 \mathrm{~N}$

$N$. parvum, on grape, in Chile, $1032 \mathrm{~N}$

Neovossia horrida, on rice, long-term crop rotation, soil tillage, fertility and severity of, 990

Nepal, A., 614N

Nephelium lappaceum (rambutan), Lasmenia sp. on, in Puerto Rico, 1313N

Nester, S. E., 577

Nettle, common. See Urtica dioica

Ngugi, H. K., 269

Niang, Y., 1311N

Niblack, T. L., 413

Nicholson, J. S., 1443

Nicoli, A., 1194N

Nicot, P. C., 719

Nicotiana spp. (tobacco)

N. rustica, Phytophthora nicotianae on, 1443

N. tabacum

Botrytis cinerea on, in China, $612 \mathrm{~N}$

Chilli veinal mottle virus in, in China, 357N

Peronospora tabacina on, detection and quantification using real-time PCR assay, 673, cover photo: June

Pythium dissotocum on, in Brazil, 354N

Rhizoctonia solani on, in Massachusetts, $496 \mathrm{~N}$

Tomato zonate spot virus in, in China,

$1484 \mathrm{~N}$, cover photo: November

Tomato spotted wilt virus in, in Italy, $611 \mathrm{~N}$

Nie, B., 113

Nie, X., 113

Nieto, A., $882 \mathrm{~N}$

Nifong, J. M., 1443

Nigrospora sphaerica

on Chinese wisteria, $219 \mathrm{~N}$

on Curcuma wenyujin, in China, 1190N,

cover photo: September

Nikolaeva, O. V., 778N

Niks, R. E., 1339

Nili, N., 455

Niranjana, S. R., 881N

Nishijima, K. A., 360N

Nivalenol (NIV), Fusarium graminearum

chemotype of, resistance to initial infection

and spread and, 31

Njambere, E. N., 78N

Njau, P., 762

Nolan, P. A., 1314N

Noll, L. W., 853

Nome, C., $771 \mathrm{~N}$

Nome, C. F., 882N

Noni. See Morinda citrifolia

Nothofagus macrocarpa, Phytophthora spp. on,

in Chile, $1193 \mathrm{~N}$

Nutter Jr., F. W., 126

Oak. See Quercus spp.

Oat. See Avena spp.

O'Boyle, P. D., 19

Ocimum basilicum (sweet basil), Peronospora

belbahrii on, in Hungary, 1034N

October syndrome, in sweet orange, cover

photo: March

O'Donnell, K., 633

Odvody, G. N., 523

Oertel, B., 368

Oidium spp. 
on papaya, in Taiwan, $1188 \mathrm{~N}$

on petunia, in United Kingdom, 361N

Oilseed rape. See Brassica napus

Ojiambo, P. S., 43, 561

Ok, C.-H., 51

Olalla-Gómez, C., 883N

Olanya, O. M., 568

Olarte, R. A., 1279

Olate, E., $1198 \mathrm{~N}$

Olea europaea (olive)

Fusarium solani on, in Argentina, 1476N

Fusicladium oleagineum on, 1139

olive fruit fly on, in Tunisia, $770 \mathrm{~N}$

Olive fruit fly. See Bactrocera oleae

Olivier, T., $495 \mathrm{~N}$

Olson, B., 1192N

Olson, H. A., 1013

Oncidium spp., Pectobacterium chrysanthemi on, in Florida, 74N

Onion. See Allium cepa

Onyeka, T. J., 618N

Opdebeeck, G., 359N

Opium poppy. See Papaver somniferum

Orchids

Carnation mottle virus in, $354 \mathrm{~N}$

Pectobacterium chrysanthemi on, $74 \mathrm{~N}$

Organic amendments, Fusarium disease and, 1116

Orobanche spp. (broomrape)

O. aegyptiaca, Fusarium solani on, in India, $75 \mathrm{~N}$

$O$. ramosa, on oilseed rape, wild mustard and wild vetch, in Greece, $1322 \mathrm{~N}$, cover photo: October

Oropeza, C., 256

Ortalda, E., $772 \mathrm{~N}$

Ortiz-Ribbing, L. M., 469

Oryza glaberrima, Xanthomonas oryzae pv. oryzae on, 441

Oryza sativa (rice)

Neovossia horrida on, long-term crop rotation, soil tillage, fertility and severity of, 990

Pantoea ananatis on, in India, 1582N

Rhizoctonia solani on, quantification of resistance components using detached tiller test under controlled conditions, 1507

Southern rice black-streaked dwarf virus in, in Vietnam, 1063

Ustilaginoidea virens on, long-term crop rotation, soil tillage, fertility and severity of, 990, cover photo: August

Xanthomonas oryzae pv. oryzae on, 441, 589

Xanthomonas oryzae pv. oryzicola on, $72 \mathrm{~N}$

Oskay, F., 222N

Osman, F., 657

Osmorhiza longistylis, Puccinia pimpinellae on, in India, $1482 \mathrm{~N}$

Ostojic, I., 883N

Otto-Hanson, L., 1370

Oudemans, P. V., 618N

Ouedraogo, L., 72N

Ownley, B. H., 1191N, 1195N, 1585N

Oxidative stress, Phytophthora melonis on cucumber and, 455

Pachyrhizus erosus (jicama), Phakopsora pachyrhizi on, in United States, 1034N

Padgham, J., 1204

Paeonia suffruticosa (tree peony),

Seimatosporium botan on, in China, 226N

Paillard, S., 1311N

Palm

16SrIV group phytoplasma on, 248

Fusarium oxysporum f. sp. canariensis on, $358 \mathrm{~N}, 1192 \mathrm{~N}$

Fusarium oxysporum f. sp. palmarum on, in Florida, 356N
Phytophthora palmivora and $P$. nicotianae on, in Italy, $768 \mathrm{~N}$

phytoplasma associated with Texas phoenix palm decline on, $1475 \mathrm{~N}$

Palm, M. E., 1034N

Palmateer, A. J., 74N, 880N

Pan, L., 1190N

Pan, R., 1031N, 1480N

Pan, S., 1320N

Pan, Y.-B., 1581N

Pande, S., 1204

Pane, A., 358N, 362N, 769N

Panebianco, A., 1194N

Pang, W., 1308

Panicum virgatum (switchgrass)

Bipolaris spp.

B. oryzae on, in New York, 1192N

B. sorokiniana on, in Tennessee, $1195 \mathrm{~N}$

B. spicifera on, in United States, 1191N

plant-parasitic nematodes as potential pathogens of, 413

Sclerotinia homoeocarpa on, in United

States, $1585 \mathrm{~N}$

Tilletia maclaganii on, in New York and

Pennsylvania, $1587 \mathrm{~N}$

Pantoea spp.

$P$. agglomerans

for control of Phytophthora erythroseptica, on potato, 24 on walnut, in China, $773 \mathrm{~N}$

$P$. ananatis, on rice, in India, $1582 \mathrm{~N}$

Papaver somniferum (poppy), Peronospora

arborescens on, in seed stocks and

symptomless infected plants, 143

Papaya. See Carica papaya

Papayiannis, L. C., 78N, 120

Paperbark. See Melaleuca quinquenervia

Paplomatas, E. J., 223N, 777N

Pappu, H. R., 1195N, 1319N, 1520

Parisi, O., 137

Park, D., 70N

Park, D. H., 589

Park, D. S., 589

Park, J. H., 1480N

Park, M. J., 1480N, 1590N

Park, S. C., 589

Parke, J. L., 337

Pascal, T., 719

Pasche, J. S., 691, 997

Paspalum vaginatum (seashore paspalum), Waitea circinata on, 515, cover photo: May

Passalora bougainvilleae, on Bougainvillea spectabilis, in Mexico, $775 \mathrm{~N}$

Passiflora spp. (passion flower)

P. edulis

Cowpea aphid borne mosaic virus in, transformation and resistance to, 1021

Fusarium oxysporum f. sp. passiflorae on, in North America, 1478N

P. mollissima, Rhizoctonia solani on, in Italy, $1194 \mathrm{~N}$

Pataky, J. K., 1492

Patel, J. S., 1558

Paterson, L., 595

Patocchi, A., 497N

Patulin, postharvest fruit rots of apple in Greece and, 666

Paul, C., 1007

Paul, P. A., 401, 1448

Paulitz, T. C., 304

Pavan, M. A., 227N

Pavelková, J., 878N

PBCVd. See Pear blister canker viroid

PBNSPaV. See Plum bark necrosis stem pittingassociated virus

Pea. See Pisum sativum

Peach. See Prunus persica

Peach latent mosaic viroid (PLMVd), in peach, quantitative real-time PCR for, 137
Peacock, K., 633

Peanut. See Arachis hypogaea

Pear. See Pyrus spp.

Pear blister canker viroid (PBCVd), in pear, in Argentina, $882 \mathrm{~N}$

Pearce, T. L., 773N

Pecan. See Carya cathayensis

Pectobacterium spp.

$P$. atroseptica, on potato, development and suppression in commercial fields, 285

$P$. carotovorum subsp. carotovorum on artichoke, in China, $1026 \mathrm{~N}$ on cabbage, in Malaysia, 491N on cucumber, in Malaysia, 1474N on potato, development and suppression in commercial fields, 285

$P$. chrysanthemi, on Oncidium spp., in

Florida, 74N

on potato, effect of potato physiology and species on disease severity, 232

Pedersen, D. K., 189, 1318N

Pedersen, J. F., 648

Peeper, T., 614N

Peiris, K. H. S., 554

Peña, E., 1198N

Peña, J. E., 1589N

Peñalver, J., $1583 \mathrm{~N}$

Peng, D. X., 1318N

Peng, Y.-L., 616N

Penicillium spp.

$P$. expansum, on apple in Greece, 666 pyrimethanil resistance and, $72 \mathrm{~N}$

$P$. griseofulvum, on apple, in Italy, $76 \mathrm{~N}$

P. oxalicum, on tomato, in Mexico, $1195 \mathrm{~N}$

Pennisetum clandestinum (kikuyugrass), Waitea circinata var. prodigu on, in California, $767 \mathrm{~N}$

Pensa, P., 877N, 1191N

Peony. See Paeonia suffruticosa

Pepino mosaic virus (PepMV)

in cherry tomatoes, in Greece, $78 \mathrm{~N}$

in tomato

in Mexico, $1035 \mathrm{~N}$

in South Africa, $767 \mathrm{~N}$

PepMoV. See Pepper mottle virus

PepMV. See Pepino mosaic virus

Pepper. See Capsicum spp.

Pepper mottle virus (PepMoV), in bell pepper,

in Taiwan, $617 \mathrm{~N}$

Pepperweed, perennial. See Lepidium latifolium

Pereira, O. L., 1194N

Pereira-Carvalho, R. C., 1196N, 1318N

Peres, N. A., $1474 \mathrm{~N}$

Perez, B. A., 774N, 1476N

Pérez, B. A., $1478 \mathrm{~N}$

Pérez Fernández, J., 771N

Perez-Egusquiza, Z., 1484N

Pérez-Martínez, J. M., 977

Pérez-Sierra, A., 874N, 1028N

Periwinkle, Madagascar. See Catharanthus roseus

Perminow, J. I. S., 1187N

Peronospora spp.

$P$. arborescens, on poppy, in seed stocks and symptomless infected plants, 143

$P$. belbahrii, on basil, in Hungary, 1034N

$P$. tabacina, on tobacco, detection and quantification using real-time PCR assay, 673, cover photo: June

Perrone, G., $877 \mathrm{~N}, 1588 \mathrm{~N}$

Perry, K., $881 \mathrm{~N}$

Perry, K. L., 619N, 1279

Persea americana (avocado)

Botryosphaeriaceae species associated with

branch cankers in California, 1465

Pestalotiopsis clavispora and Pestalotiopsis

spp. on, in Chile, $492 \mathrm{~N}$

Raffaelea lauricola on in California, $1189 \mathrm{~N}$ 
fungicides for control of, 977

Persea borbonia (redbay), Raffaelea lauricola on, fungicides for control of, 977

Persimmon, sweet. See Diospyros kaki

Perumal, R., 523

Pestalotiopsis spp., on avocado, in Chile, 492N

Peters, D., $1485 \mathrm{~N}$

Peters, R. D., $873 \mathrm{~N}$

Peterson, G. L., 478

Pethybridge, S. J., 773N, 1478N

Petunia, Oidium longipes on, in United

Kingdom, 361N

Phaeoacremonium spp., on grape

in Iran, 1034N

in Spain, 615N

Phaeomoniella chlamydospora

on grape, propagation process and, 1040 isolation from vineyard weeds, 803

Phakopsora pachyrhizi

on jicama, in United States, 1034N

multiplexed, quantitative PCR assays for, exogenous controls, negative cell veracity and, 343

on soybean

characterizing resistance, 577

comparison of visual rust assessments

and DNA levels in genotypes varying in resistance, 1007

crop monitoring, spore trapping, and aerobiological modeling for prediction of, 1346

dynamics in sequential plantings in

Nigeria, 43

effects of shade intensity and duration on, 485

effects of silicon applications on, 317

epidemiology in sentinel plots in Florida, 744

Phalaenopsis orchids, Carnation mottle virus in, $354 \mathrm{~N}$

Phaseolus spp. (bean)

begomoviruses associated with bean golden mosaic disease in, 901

P. lunatus (lima bean), Phytophthora

phaseoli on, in Virginia, $71 \mathrm{~N}$

P. vulgaris

Colletotrichum lindemuthianum on, prevalent races and resistance sources in North Dakota, 408

Phytophthora capsici on, in New York, $1028 \mathrm{~N}$

Sclerotinia sclerotiorum on, variations in isolates from multisite resistance screening locations, 1370

Sida micrantha mosaic virus in, in Brazil, 1196N

soybean cyst nematode on, reproduction over multiple generations, 1239

Philotheca myoporoides (long-leaf waxflower), Fusarium oxysporum on, in Italy, 877N

Phoenix canariensis (Canary Island date palm),

Fusarium oxysporum on, 356N, 358N, 1192N

Phoenix roebelenii (pigmy date palm),

phytoplasma associated with Texas phoenix

palm decline on, $1475 \mathrm{~N}$

Phoma spp.

$P$. aquilegiicola, on fan columbine, in Italy, $880 \mathrm{~N}$

$P$. bellidis, on Eleocharis dulcis, in China, $1190 \mathrm{~N}$

P. dictamnicola, on fraxinella, in China, $771 \mathrm{~N}$ on pea

in Australia, 1590N

pathogen survival in field-pea-cropping soils of Australia, 1217

Phomopsis spp.

$P$. amaranthicola, for control of pigweed and waterhemp in pumpkin and soybean, 469
P. cucurbitae, on cantaloupe, in Italy, $1317 \mathrm{~N}$

$P$. longicolla, on soybean, viral infection and, 530

P. perniciosa, on cherry, in China, $1316 \mathrm{~N}$ Phytophthora spp.

P. capsici

genetic structure from creek used for irrigation in Michigan, 1358

on pepper, cover photo: May

sensitivity of isolates to fluopicolide, 1414

on snap bean, in New York, 1028N

variation in phenotypic characteristics of isolates from worldwide collection, 1075

wild type sensitivity and mutation analysis for resistance risk to fluopicolide in, 1535

characterization on floriculture crops in

North Carolina, 1013

$P$. cinnamomi, effects of fuel reduction

treatment on incidence in southern

Appalachian forest, 811

P. citrophthora

on Nothofagus macrocarpa, in Chile, $1193 \mathrm{~N}$

on Rosa indica, in Italy, $358 \mathrm{~N}$

on woody ornamentals, in Hungary, $1193 \mathrm{~N}$

P. colocasiae, on taro, in Nigeria, $618 \mathrm{~N}$

P. erythroseptica, on potato

mefenoxam, phosphorous acid

fungicides and, 997

mefenoxam sensitive and resistant,

fitness under fungicide selection pressure, 691

selection of biocontrol agents for, 24

on Fraser fir, 537

$P$. infestans

genotype US23, in Canada, 873N, cover photo: July

on soda apple, in Colombia, $875 \mathrm{~N}$

P. infestans, LATEBLIGHT simulation model for, 839

P. kernoviae, on Rhododendron ponticum,

13, cover photo: January

P. melonis, on cucumber, 455

P. nicotianae

on Aeonium arboreum, in Italy, 362N

on Nicotiana rustica, 1443

on Nothofagus macrocarpa, in Chile, $1193 \mathrm{~N}$

on onion, in United States, $1028 \mathrm{~N}$

on Rhododendron spp., in Greece, $777 \mathrm{~N}$

on tomato, in New Mexico, 1029N

on windmill palm, in Italy, $769 \mathrm{~N}$

P. sp. "niederhauserii," on lentisk, in Italy, $618 \mathrm{~N}$

P. palmivora

on lavender, in Turkey, $1035 \mathrm{~N}$

on windmill palm, in Italy, $769 \mathrm{~N}$

$P$. phaseoli, on lima bean, in Virginia, $71 \mathrm{~N}$

PHYTOPHTHORA-ID.org for identification of, 337

P. ramorum

on biltberry, in Norway, $355 \mathrm{~N}$

on Rhododendron spp., 13, 223N

root infections challenging management of,

13, cover photo: January

on strawberry, in Japan, 1270

Phytophthora-ID.org, overview of, 337

Phytoplasma diseases. See also Candidatus

Phytoplasma

in Amaranthus hypochondriacus, $871 \mathrm{~N}$

in Arabian pea, in Australia, 226N

in coneflower, $773 \mathrm{~N}$, cover photo: June

in date palm, $1475 \mathrm{~N}$

in eggplant, in Oman, 360N

in grape, in Croatia, $353 \mathrm{~N}$ in palm, 248, 256, cover photo: March in papaya, in Taiwan, $1581 \mathrm{~N}$

in potato, in China, $871 \mathrm{~N}$

in soybean, in Malawi and Mozambique,

492N, cover photo: April

in Stevia rebaudiana, in India, $1582 \mathrm{~N}$

in walnut, in Iowa, 1474N

Pianzzola, M. J., 1292

Pichia anomala strain K, for control of apple blue mold, screening UV protectants for preharvest application, 311

Picoaga, A., 776N, 1583N

Picos-Munoz, P. A., 1195N

Pierce's disease. See Xylella fastidiosa

Pierson, E., 1542

Pietersen, G., 1026N

Pignatello, J. J., 960

Pilidiella granati, on pomegranate, in Greece, $79 \mathrm{~N}$

Pilidium concavum, on strawberry, in Belgium, $1029 \mathrm{~N}$, cover photo: August

Pine wood nematode. See Bursaphelenchus xylophilus

Pineapple lily. See Eucomis vandermerwei

Pinho, D. B., 1194N

Pink ipê. See Tabebuia impetiginosa

Pinnow, D. L., 1385

Pinto, H. J., 1588N

Pintos Varela, C., 221N, 1315N

Pinus spp. (pine)

P. flexilis, Cronartium ribicola on, in

Arizona, 494N

$P$. pinaster, Bursaphelenchus xylophilus on, in Spain, $776 \mathrm{~N}$

$P$. radiata, Cylindrocarpon pauciseptatum on, in Spain, $874 \mathrm{~N}$

P. sylvestris, Mycosphaerella pini on, in Norway, $875 \mathrm{~N}$

Pirc, M., 70N

Pistacia lentiscus (lentisk), Phytophthora sp.

"niederhauserii" on, in Italy, 618N

Pistacia vera (pistachio)

Alternaria alternata on, QoI fungicideresistant, 178

Colletotrichum gloeosporioides on, in

China, $1314 \mathrm{~N}$

Pisum sativum (pea)

ascochyta blight of, pathogen survival in

field-pea-cropping soils of Australia, 1217

Phoma herbarum on, in Australia, 1590N

Pitsi, B. E., 363N

Pittman, R. N., 263

Pittosporum tobira, Eggplant mottled dwarf virus in, in Spain, $75 \mathrm{~N}$

Pityopsis ruthii (Ruth's golden aster),

Golovinomyces cichoracearum on, in

Tennessee, $879 \mathrm{~N}$

Plant growth regulators, Sclerotinia

homoeocarpa on turfgrasses and, 51, 1433

Plavec, J., 353N

Pleurotus eryngii (king oyster mushroom),

Cladobotryum mycophilum on, in Spain,

$1030 \mathrm{~N}$

PLMVd. See Peach latent mosaic viroid

Ploetz, R. C., 977, 1589N

Plum. See Prunus domestica

Plum bark necrosis stem pitting-associated

virus (PBNSPaV), in stone fruit trees, in

China, $1483 \mathrm{~N}$

Plum pox virus (PPV), in peach, in Bulgaria, $1320 \mathrm{~N}$

PMTV. See Potato mop-top virus

Poa spp.

$P$. апnиа (annual bluegrass)

resistance of closely mown to snow mold pathogens, 839

Waitea circinata var. circinata on, $78 \mathrm{~N}$

$P$. pratensis (Kentucky bluegrass), Puccinia coronata on, in United States, 1547 
Podosphaera spp.

P. euphorbiae-helioscopiae, on Euphorbia pekinensis, in China, $1314 \mathrm{~N}$, cover photo: October

P. fusca, on Cosmos caudatus, in Malaysia, $495 \mathrm{~N}$

P. leucotricha, on peach, 719 , cover photo: June

P. xanthii

on papaya, in Taiwan, $1188 \mathrm{~N}$

on summer squash and cantaloupe, 461 on watermelon, in Florida, 1586N

Poinsettia. See Euphorbia pulcherrima

Pokorný, R., 79N

Poli, A., 496N, 877N, 878N, 1191N, 1317N, $1481 \mathrm{~N}$

Poliakoff, F., 1311N

Polizzi, G., 195, 877N, 1030N, 1194N, 1588N

Polymyxa graminis f. sp. temperata, as vector of soilborne cereal viruses, in Czech Republic, $353 \mathrm{~N}$

Pomegranate. See Punica granatum

Pomelo. See Citrus grandis

Pondberry. See Lindera melissifolia

Pondspice. See Litsea aestivalis

Popko, J. T., 51

Poppy. See Papaver somniferum

Pormarto, S. H., 1239

Pospieszny, H., 1475N

Postic, J., 612N

Pot marigold. See Calendula officinalis

Potato. See Solanum tuberosum

Potato mop-top virus (PMTV), in potato, in

Washington state, $1483 \mathrm{~N}$

Potato virus $M$ (PVM), in bittersweet

nightshade, in New York, 619N

Potato virus $Y$ (PVY)

recognition and molecular discrimination of severe and mild variants of, in Canada, 113

transmission efficiency of strains of by five aphid species, 1279

Potato yellowing virus (PYV), in Solanum

phureja, in Ecuador, 355N

Prakash, H. S., $881 \mathrm{~N}$

Predajna, L., 38

Prehn, D., 490N, 1032N

Press, C. M., 337

Pretorius, Z. A., 611N, 1188N

Price, J. A., 4, 1516

Price, L. E., 212

Prischmann, J., 408

Probst, C., 212

PROCULTURE model, for Mycosphaerella graminicola in wheat, 384

Proffer, T. J., 927

Prom, L. K., 523

Propiconazole, for Monilinia fructicola, 828

Prunus spp.

Candidatus Liberibacter asiaticus on, 431

P. domestica (plum), Microcyclosporella mali on, in Poland, 493N

P. dulcis (almond), Xylella fastidiosa on analysis of xylem fluid in cultivars differing in resistance to, 166 influence of inoculation date on, 158

$P$. laurocerasus (cherry laurel), Xanthomonas arboricola pv. pruni on, in Italy, $74 \mathrm{~N}$

little cherry disease in, in Czech Republic, $1197 \mathrm{~N}$

Little cherry virus 2 in, in China, 1484N

Monilinia spp. on

in China, population structure of, 1284

in New York, Rhode Island, and

Massachusetts, $1584 \mathrm{~N}$

P. mume (Japanese apricot), Botryosphaeria dothidea on, in Taiwan, $77 \mathrm{~N}$

$P$. persica (cherry), Cherry green ring mottle virus in in China, $1319 \mathrm{~N}$

$P$. persica (peach)

Botryosphaeria spp. on, in China, 1378

Cherry green ring mottle virus in, in China, $1319 \mathrm{~N}$

Monilinia fructicola on, in China, $225 \mathrm{~N}$

Peach latent mosaic viroid (PLMVd) in quantitative real-time PCR for, 137

Plum pox virus in, in Bulgaria, $1320 \mathrm{~N}$

Podosphaera leucotricha on, 719, cover photo: June

Xylella fastidiosa on, in New Mexico, $871 \mathrm{~N}$

P. persicola (cherry), Phomopsis perniciosa on in China, $1316 \mathrm{~N}$

Plum bark necrosis stem pitting-associated virus in, in China, $1483 \mathrm{~N}$

Pruvost, O., 774N, 1311N, 1312N

Psammotettix provincialis, Wheat dwarf virus in wheat and barley and, $76 \mathrm{~N}$

Pseudocercospora fuligena, on tomato, carrying introgressions from Solanum habrochaites, 394

Pseudomonas spp.

P. cannabina pv. alisalensis, on Brassica spp in Australia, 1027N in California, $71 \mathrm{~N}$

$P$. fluorescens, for control of Fusarium oxysporum f. sp. cubense on banana, 951

P. koreensis, for control of Phytophthora erythroseptica, on potato, 24

P. lini, for control of Phytophthora erythroseptica, on potato, 24

$P$. syringae pv. actinidiae, on kiwifruit in France, $1311 \mathrm{~N}$ in Spain, $1583 \mathrm{~N}$

$P$. syringae pv. porri, on onion, in Korea, $1311 \mathrm{~N}$

Pseudoperonospora cubensis, on cucurbits in Czech Republic, 878N, cover photo: July formation and infectivity of oospores, $874 \mathrm{~N}$

in Michigan, dynamics in commercial fields, 1392

Pseudophoenix sargentii (palm), 16SrIV group phytoplasma on, 248

$\mathrm{Pu}, \mathrm{X} ., 431$

Puccinia spp.

$P$. carthami, on safflower, cover photo:

March

P. coronata

on Kentucky bluegrass, in United States, 1547

on oat, virulence in United States 20062009, 1258

$P$. graminis f. sp. tritici

race TTKSK (Ug99): resistance to in Agenome diploid relatives of wheat, 941 sources of resistance to, 762; in Zimbabwe and Mozambique, 1188N on wheat, isolates with virulence to resistance genes $S r 31$ and $S r 24,1591 N$

$P$. hemerocallidis, on daylily, effect of postsymptom application of fungicides on urediniospore production by, 325

P. kuehnii, on sugarcane, $357 \mathrm{~N}, 640$

$P$. pimpinellae, on Osmorhiza longistylis, in India, $1482 \mathrm{~N}$

$P$. polysora, on soybean, detection and discrimination vs. Puccinia sorghi, 624

$P$. psidii, on paperbark, in California, 1314N on purple false brome grass, 1339

$P$. sorghi, on soybean, detection and discrimination vs. Puccinia polysora, 624

$P$. thaliae, on canna lily, in Louisiana, $353 \mathrm{~N}$

P. triticina

resistance in A-genome diploid relatives of wheat, 941 on wheat: effect of postsymptom application of fungicides on urediniospore production by, 325; $L r 21$ gene and, 1032N; physiologic specialization in U.S. in 2009, 935; in South Africa, $611 \mathrm{~N}$

Pueraria montana var. lobata (kudzu),

Synchytrium minutum on, in Korea, 358N

Pumpkin. See Cucurbita spp.

Punica granatum (pomegranate)

Ceratocystis fimbriata on, in China, 776N

Colletotrichum gloeosporioides on, in

Greece, 872N

Pilidiella granati on, in Greece, $79 \mathrm{~N}$

Putman, A. I., 1433

PVM. See Potato virus $M$

PVY. See Potato virus $Y$

Pyrenochaeta lycopersici, on tomato, soil solarization for control of, 195

Pyrenophora spp.

on barley, genetic characterization of resistance genes, 19

on wheat, detection of QoI fungicideresistant isolates, 1558

Pyrethrum. See Tanacetum cinerariifolium

Pyrimenthanil, Penicillium expansum on apple,

resistance and, $72 \mathrm{~N}$

Pyrus spp. (pear)

Erwinia amylovora on kasugamycin for management of, 448 loop-mediated isothermal amplification for rapid detection of, 423

Pear blister canker viroid in, in Argentina, $882 \mathrm{~N}$

Pythium spp.

P. dissotocum, on tobacco, in Brazil, 354N on geranium, mefenoxam and, dosage effect and resistance, 1233

recovery from forest nursery soils in Oregon and Washington, 547

$P$. sterilum, on blueberry, in United States, $614 \mathrm{~N}$

PYV. See Potato yellowing virus

Qiao, Q., 356N

Qin, B.-X., 1483N

Qin, G.-Z., 63

Qin, X.-Y., 357N

Qin, Y.-H., 356N

QoI fungicides

for Alternaria alternata, on pistachio, resistance to, 178

for Cercospora zeae-maydis, on corn, resistance to, 189

for Puccinia spp., on wheat and daylily, effect on urediniospore production, 325 for Pyrenophora tritici-repentis on, on wheat, detection of resistant isolates, 1558 for Venturia inaequalis, on apple, G143A mutation and, 927

Qu, W. W., 773N

Quemin, M. F., 775N

Quercus spp.

O. castaneifolia, Biscogniauxia

mediterranea on, in Iran, $876 \mathrm{~N}$

Ceratocystis fagacearum on, changes and successes in managing in U.S., 888

$Q$. phillyraeoides, Erysiphe quercicola on, in

Korea, 77N

Q. virginiana, Diplodia corticola on, in

Florida, $1027 \mathrm{~N}$

Quesada-Ocampo, L. M., 1080, 1358

Raes, J. J., 1584N

Raffaelea lauricola

on avocado, in California, $1189 \mathrm{~N}$ on avocado and redbay, fungicides for control of, 977

in Miami-Dade County, Florida, 1589N on pondspice, in Florida, 1588N on pondspice and pondberry, 1056 
on sassafras, in Mississippi, 1479N

Ragweed, giant. See Ambrosia trifida

Rai, P. K., 75N

Rainey, K. M., 878N

Ralstonia solanacearum

on Mandevilla splendens, in United States, $614 \mathrm{~N}$

on potato, in Uruguay, genetic diversity and aggressiveness, 1292

Ramallo, A. C., 1477N

Rambutan. See Nephelium lappaceum

Ramírez, P., 901, 1482N

Ramirez de Lopez, M., 613N

Ramírez-Mendoza, M. R., 772N

Ramos, C., 683

Ramos-Reynoso, E. D., 901

Rampersad, S. N., 248, 1244, 1313N

Ramularia didyma, on ranunculus, in California, $872 \mathrm{~N}$

Ramulispora sorghi

on chickpea, 860

on sorghum, disease severity and

microsclerotium properties, 853

Rana, G. L., 72N

Randall, J. J., 871N, 1028N, 1029N

Ranunculus asiaticus, Ramularia didyma on, in California, $872 \mathrm{~N}$

Rao, W.-L., 1484N

Rape, oilseed. See Brassica napus

Ravi Sankar, N., 1476N

Ravindran, A., 1542

Ravnikar, M., 70N

Ray, J. D., 1159

Razdan, V. K., 1482N, 1587N

Rebollar-Alviter, A., 772N

Red melon beetle. See Aulacophora foveicollis

Redbay. See Persea borbonia

Redondo Fernández, V., 221N, 1315N

Reid, L. S., 1056

Remote sensing, of wheat infected by Wheat

streak mosaic virus, 4

Resistance. See also Host resistance

of Alternaria alternata, against QoI fungicides, 178

of Botrytis cinerea, against multiple fungicides in N. German small-fruit production, 1263

of Cercospora zeae-maydis on corn, against QoI fungicides, 189

of Fusarium spp. on potato, against fludioxonil, $228 \mathrm{~N}$

of Monilinia fructicola, to methyl benzimidazole carbamates, $497 \mathrm{~N}$

of Penicillium expansum, to pyrimethanil, $72 \mathrm{~N}$

of Phytophthora capsici, against fluopicolide, 1535

of Phytophthora erythroseptica, against mefenoxam, parasitic fitness and, 691

of Pythium spp. on geranium, against mefenoxam, dosage effect and, 1233 of Sclerotinia homoeocarpa, to fungicides and plant growth regulators, 51

of Venturia inaequalis on apple against multiple fungicides, 921, cover photo: August

against QoI fungicides, G143A mutation and, 927

Restrepo, S., 875N

Rew, L. J., 1099

Rey, J. Y., 774N, 1311N

Rey, M. E. C., 767N

Reynolds, K., 413

Rezaee, S., 882N

Rezazadeh, R., 419

Rezende, J. A. M., 363N, 613N, 1021

Rhizoctonia spp.

anastomosis group $\mathrm{F}$, on banana, $490 \mathrm{~N}$

on azalea (Rhododendron spp.), seasonal prevalence in growing medium, leaf litter, and stems, 705

$R$. oryzae, on barley, preplant glyphosate applications for management of, 304

$R$. solani

AG-4 on pink ipê, in Italy, $78 \mathrm{~N}$

on banana passionflower, in Italy, 1194N

on barley, preplant glyphosate

applications for management of, 304

on rice, quantification of resistance

components using detached tiller test

under controlled conditions, 1507

on tobacco, in Massachusetts, $496 \mathrm{~N}$

Rhodiola sachalinensis, Fusarium verticillioides

on, in China, 222N

Rhododendron spp.

Calonectria colhounii on, in Belgium, $1477 \mathrm{~N}$

Neofusicoccum spp. on, in Spain, 221N

Phytophthora spp. on, in Greece, 223N, $777 \mathrm{~N}$

R. ponticum, Phytophthora spp. on, 13, cover photo: January

Rhizoctonia spp. on, seasonal prevalence in growing medium, leaf litter, and stems, 705

Rhouma, A., 770N

Rhs genes, Xanthomonas oryzae pv. oryzae on rice, real- time bio-PCR using pathovarspecific primers based on, 589

Ribeiro, S. G., 1196N

Ribes nigrum (black currant), Cronartium

ribicola on, in Connecticut, $1589 \mathrm{~N}$

Riccioni, L., 612N

Rice. See Oryza sativa

Richter, B. S., 537

Ricinnus communis (castor bean), Cercospora coffeicola on, in Brazil, 1479N

Rideout, S. L., 71N

Riggins, J. J., 1479N

Riley, D., 881N, 1520

Rinehart, T. A., 705

Ristaino, J. B., 673

Ristic, D., 226N, 491N, 1035N

Rivera-Vargas, L. I., 1313N

Rivoal, C., $1311 \mathrm{~N}$

Rizza, C., 362N, 769N

Rizzo, D. M., 13

Roberts, P. D., 360N, 1586N

Robertson, A. E., 126

Robles-Hernandez, L., 778N

Roca, L. F., 1139

Rocha, A. B., 354N

Rocket. See Diplotaxis tenuifolia; Eruca sativa

Rodríguez, A., 1328

Rodriguez-Carres, M., 490N, 705

Rojas, A., 228N, 614N, 1194N

Rolling-circle amplification method, for

detection of Banana streak virus, and

discrimination between integrated and episomal virus sequences, 57

Rooney, A. P., 24

Rooney-Latham, S., 224N, 356N, 361N, 1478N

Root-knot nematode. See Meloidogyne spp.

Rosa indica, Phytophthora citrophthora on, in Italy, 358N

Rosales, I. M., $1198 \mathrm{~N}$

Roscoe, J., 1034N

Rosenberger, D. A., 1179

Roskamp, G. K., 469

Rossini, M., 882N

Rosskopf, E. N., 360N

Rosso, M. L., 878N

Rotylenchulus reniformis (Reniform nematode), on cotton, Catenaria auxiliaris parasitizing, $490 \mathrm{~N}$

Rouse, M. N., 762, 941

Rovira, M., 1565

Rowhani, A., 657

Roy, A., 913
Rubin, A. E., 874N

Rubio, I., 1027N

Rubus sp. (blackberry)

Botrytis cinerea on, in South Carolina, $1481 \mathrm{~N}, 1592 \mathrm{~N}$

Diaporthe eres on, in Croatia, $612 \mathrm{~N}$

Ruhl, G., 614N

Rush, C. M., 4, 1516

Rush, T. A., 353N

Russo, J. M., 1346

Ruth's golden aster. See Pityopsis ruthii

Ryšánek, P., 353N

Saalau Rojas, E., 729

Sabal mexicana (palm), 16SrIV group

phytoplasma on, 248

Saccharum spp. (sugarcane)

Leifsonia xyli subsp. xyli on, in Pakistan, $1581 \mathrm{~N}$

Puccinia kuehnii on, 357N, 640

Sacristán-Pérez-Minayo, G., 883N

Sadowsky, J. J., 1187N

Safflower. See Carthamus tinctorius

Sago, C., $778 \mathrm{~N}$

Sakuma, F., 1124

Salamone, A., 358N

Salazar, S. M, 1477N

Saleh, A. A., 853

Salehi, M., 419

Salgado, J. D., 1448

Salinas, A., 683

Salix alba (white willow), Brenneria salicis on, in Italy, $772 \mathrm{~N}$

Samad, A., 1582N

Samavi, S., 419

Samuelian, S. K., 298

Sanabria, A., 1292

Sanches, A. L., 104

Sang, L. W., 494N

Sanni, A., 441

Sanogo, S., 1583N

Santiago-Santiago, V., 775N

Santos, M. A., 104

Sariah, M., 495N

Saskatoon serviceberry. See Amelanchier alnifolia

Sassafras albidum, Raffaelea lauricola on, in

Mississippi, 1479N

Saumtally, A. S., 357N

Savary, S., 1204, 1507

Savocchia, S., 298

SbDV. See Soybean dwarf virus

SBFS. See Sooty blotch and flyspeck

Scanu, B., 618N

Scarito, G., 358N

Schanze, M., 497N

Scheck, H. J., 224N, 361N, 1478N

Schilder, A. M. C., 614N, 768N, 770N, 1187N

Schisandra chinensis, Botrytis cinerea on, in China, 769N

Schisler, D. A., 24

Schmale, D. G., 1458

Schnabel, G., 772N, 1481N, 1482N, 1592N

Schneider, W. L., 945

Schroeder, B. K., 285

Schroeder, K. L., 304

Schubert, T., 1589N

Schubert, T. S., 1475N

Schwartz, H. F., 1319N

Scilla peruviana, Embellisia hyacinthi on, in

California, 356N

Sclerotinia spp.

S. homoeocarpa on switchgrass, in United States, $1585 \mathrm{~N}$ on turfgrasses: effects of dew removal and mowing frequency on fungicide performance, 1427; effects of plant growth regulators and mowing frequency on, 1433, cover photo: 
November; in vitro assessment of resistance to fungicides and plant growth regulators, 51

S. sclerotiorum

on bean, variations in isolates from multisite resistance screening locations, 1370

on blueberry, in Argentina, 774N

on fan columbine, in Italy, $1481 \mathrm{~N}$

on Volkamer lemon, in Italy, 1030N

Sclerotium rolfsii, on carrot, in Korea, $1585 \mathrm{~N}$

SCMV. See Sugarcane mosaic virus

Scortichini, M., 772N

Scots pine. See Pinus sylvestris

Scott, E. S., 1217

Scott, J. B., 773N

Scuderi, G., 1030N

Scutellaria lateriflora (skullcap), Verticillium

dahliae on, 1147, cover photo: September

Scutellonema brachyurum (spiral nematode), on lilyturf, in United States, 74N

Seashore paspalum. See Paspalum vaginatum

Sechium edule (chayote), Squash leaf curl

Philippines virus (SLCPHV) in, in Taiwan, 1197N

Sedláková, B., 878N

Seem, R. C., 279

Seifers, D. L., 183, 1516

Seijo, T. E., $1474 \mathrm{~N}$

Seimatosporium botan, on tree peony, in China $226 \mathrm{~N}$

Seiridium unicorne, on Cupressus macrocarpa, in California, $619 \mathrm{~N}$

Seol, Y.-J., 589

Septoria citri, on Citrus clementina, in Italy, $873 \mathrm{~N}$

Serce, C. U., $1035 \mathrm{~N}$

Serrato-Diaz, L. M., 1313N

Šeruga Music, M., 353N

Serviceberry, Saskatoon. See Amelanchier alnifolia

Sesamum indicum (sesame), Cowpea aphid-

borne mosaic virus in, in Paraguay, $613 \mathrm{~N}$

Shahazad, A., 1581N

Shallot latent virus (SLV), in garlic, in Brazil, $227 \mathrm{~N}$

Sharifnabi, B., 455

Sharma, K., 492N, 618N

Sharma, M., 1204

Sharma, O. P., 1584N

Sharma, P., 75N, 1584N

Sharma, P. N., 1584N

Sharma, S. K., 1584N

Shen, Y. M., 874N

Sherman, D. J., 945

Shetty, K., 228N

Shew, H. D., 1443

Shi, J.-X., 612N

Shi, X.-Q., 63

Shim, H. S., $1311 \mathrm{~N}$

Shim, H.-S., $1585 \mathrm{~N}$

Shin, H. D., 1317N, 1480N, 1590N

Shin, K., 633, 1027N, 1588N

Shirvani, M., 455

Shukla, A. K., 1582N

Shung, D. P., 1197N

Siampour, M., 419

Sida micrantha mosaic virus (SimMV), in bean, in Brazil, 1196N

Sida sp., Candidatus Phytoplasma brasiliense on, in Brazil, 363N

Siddique, K. H. M., 226N

Siddiqui, S. A., 75N

Siddiqui, Y., 495N

Sidoti, A., 776N

Sierotzki, H., 1558

Signoret, P. A., 70N

Sijam, K., 491N, 1312N, 1474N

Sikora, E. J., 1034N
Silicon

Phakopsora pachyrhizi on soybean and, 317

Phytophthora melonis on cucumber and, 455

Silva-Rojas, H. V., 772N

Silvestre, R., 355N

Sim, S. T., 657

Simmons, E., 751

Simmons, E. G., 356N

SimMV. See Sida micrantha mosaic virus

Sinapis arvensis (wild mustard), branched broomrape on, in Greece, $1322 \mathrm{~N}$, cover photo: October

Singh, B., 1482N, 1587N

Singh, J., 1582N

Singh, M., 113, 1582N

Singh, P., 1197N

Singh, R., 1192N

Singh, R. P., 113

Siri, M. I., 1292

Sirococcus tsugae, on Eastern hemlock, in Georgia, $612 \mathrm{~N}$

Sivasithamparam, K., 712

Siverio, F., 1328

Škoric, D., 353N

Skullcap. See Scutellaria lateriflora

Sletten, A., 1187N

Slininger, P. J., 24

Sloan, J. M., 24

Sly, L. I., 1109

SMAMV. See Snake melon asteroid mosaic virus

Smiley, R. W., 983

Smith, D. R., 612N

Smith, E. A., 735

Smith, J. A., 633, 1027N, 1588N, 1589N

Smith, J. R., 1159

Smits, T. H. M., 497N

SMV. See Soybean mosaic virus

Snake melon asteroid mosaic virus (SMAMV), in cucurbits, 153

Snowball, R., 226N

Soda apple. See Solanum viarum

Soengas, P., 292

Soil solarization

Fusarium disease and, 1116

Fusarium oxysporum f. sp. vasinfectum on cotton and, 967

for Pyrenochaeta lycopersici on tomato, 195

Soko, T., $1188 \mathrm{~N}$

Solanum spp.

S. dulcamara (bittersweet nightshade), Potato virus $M$ in, in New York, 619N

$S$. habrochaites, tomato lines carrying introgressions from, Pseudocercospora fuligena on, 394

S. lycopersicum (tomato) Candidatus Liberibacter solanacearum on, in U.S., in Mexico, 1026N Clavibacter michiganensis subsp. michiganensis on: in Italy, 221N, cover photo: February; as seedborne pathogen, 1328

Penicillium oxalicum on, in Mexico, $1195 \mathrm{~N}$

Pepino mosaic virus in: in Greece, $78 \mathrm{~N}$; in Mexico, 1035N; in South Africa, $767 \mathrm{~N}$

Phytophthora infestans on, in Canada, $873 \mathrm{~N}$

Phytophthora nicotianae on, in New Mexico, 1029N

Pseudocercospora fuligena on, introgressions from Solanum habrochaites and, 394

Pyrenochaeta lycopersici on, soil solarization for control of, 195

Tomato chlorosis virus in: in Georgia, $881 \mathrm{~N}$; in Hungary, 363N; in Sudan, $1592 \mathrm{~N}$; cover photo: December
Trichothecium roseum on, in Brazil, $1318 \mathrm{~N}$

Xanthomonas gardneri on, in Ohio and Michigan, 1584N

S. melongena (eggplant), 16SrII-D group phytoplasma in, in Oman, 360N

S. phureja, Potato yellowing virus in, in Ecuador, $355 \mathrm{~N}$

S. tuberosum (potato)

Alternaria alternata on, in South Africa, $363 \mathrm{~N}$

Candidatus Liberibacter solanacearum on, improved PCR detection of, 1542

Candidatus Phytoplasma asteris on: in Alaska, $767 \mathrm{~N}$; in China, $777 \mathrm{~N}$

clover proliferation group phytoplasmas (16SrVI-A) on, in China, 871N

Fusarium torulosum on, in United States, $1194 \mathrm{~N}$

golden potato cyst nematode on, in

Bosnia and Herzegovina, 883N

Pectobacterium spp. on: development and suppression in commercial fields, 285; effect of potato physiology and pathogen taxa on disease severity, 232

Phytophthora erythroseptica on: mefenoxam, phosphorous acid fungicides and, 997; mefenoxam sensitive and resistant, fitness under fungicide selection pressure, 691; selection of biocontrol agents for, 24

Phytophthora infestans on: in Canada, 873N; LATEBLIGHT simulation model for, 839

Potato mop-top virus in, in Washington state, $1483 \mathrm{~N}$

Ralstonia solanacearum on, in Uruguay, genetic diversity and aggressiveness, 1292

Spongospora subterranea on, in Sri Lanka, 1033N

Streptomyces turgidiscabies on, lopsided oat green manure for suppression of, 1124

Verticillium dahliae on, management with suppressive green manures, previous cropping history and, 568

S. viarum (soda apple), Phytophthora

infestans on, in Colombia, $875 \mathrm{~N}$

Solarization. See Soil solarization

Solheim, H., 875N

Solórzano-Morales, A., 497N

Somda, I., 1312N

Song, F. M., 73N

Song, J., $1320 \mathrm{~N}$

Song, J. G., 879N

Song, J. H., 1190N

Sood, S., 640

Sooty blotch and flyspeck (SBFS)

on apple, variability among forecast models for, 1179

new view of, 368, cover photo: April on plum, in Poland, 493N

Sorghastrum nutans (Indiangrass),

Colletotrichum caudatum on, in New York, $1189 \mathrm{~N}$

Sorghum

Bipolaris spicifera on, in Turkey, 495N

Fusarium spp. in air and soil associated with, 648

Ramulispora sorghi on, disease severity and microsclerotium properties, 853

Sporisorium reilianum on, 523

Sorrentino, R., 611N

Soto-Arias, J. P., 530

Soukainen, M., 615N

Soulioti, N., 223N

Southern rice black-streaked dwarf virus

(SRBSDV), in rice, in Vietnam, 1063 
Southwick, C., $876 \mathrm{~N}$

Souza, A. G. C., 1479N

Souza, E. B., 793

Souza, M. V., 354N

Soybean. See Glycine max

Soybean cyst nematode. See Heterodera glycines

Soybean dwarf virus (SbDV), acquisition and transmissibility by Aphis glycines, 945

Soybean mosaic virus (SMV), in soybean,

Phomopsis longicolla infection and, 530

Soybean sudden death syndrome (SDS). See

Fusarium virguliforme

Soylu, E. M., 219N

Soylu, S., 219N, 1035N, 1317N

Spadaro, D., 76N

Sparks, A. H., 1204

SPCSV. See Sweet potato chlorotic stunt virus

Spector, T., 633

Spencermartinsia viticola, on citrus, in California, $770 \mathrm{~N}$

Sphaeropsis pyriputrescens, on apple, post-

harvest fungicides for control of, 1075

Spinach, malabar. See Basella alba

Spiroplasma citri, on Madagascar periwinkle, in

Southeast Asia, 1312N

Spirotetramat, for cereal cyst nematode on wheat, 983

SPLCV. See Sweet potato leaf curl virus

Spongospora subterranea, on potato, in Sri

Lanka, $1033 \mathrm{~N}$

Spore trapping, for predicting Phakopsora pachyrhizi incursions, 1346

Sporisorium reilianum, on sorghum, 523

Spotts, R. A., 279

Spurgeon, D. W., 967

Squash. See Cucurbita pepo

Squash leaf curl Philippines virus (SLCPHV), in chayote, in Taiwan, $1197 \mathrm{~N}$

Squash mosaic virus, in pumpkin, in Czech Republic, $1321 \mathrm{~N}$

Squash yellow mild mottle virus, in bean crops, in Nicaragua, 901

SRBSDV. See Southern rice black-streaked dwarf virus

Sreeramulu, A., $1476 \mathrm{~N}$

Srinivasachary, S., 1507

Srinivasan, R., 881N, 1520

Sseruwagi, P., 1195N

Stagonospora nodorum, on wheat, degree-day model for the latent period of, 561

Stamler, R. A., 1028N, 1029N

Stammler, G., 1558

Stankovic, I., 226N, 491N, 1035N

Stanosz, G. R., 612N

Stea, G., 877N, 1588N

Steadman, J. R., 1370

Steel, C. C., 298

Steffenson, B. J., 19

Steinberg, C., 951

Stenglein, S. A., 496N

Stensvand, A., 279, 1031N

Stephenson, A. G., 751

Stevenson, K. L., 263

Stevia rebaudiana, group 16SrXXIV

phytoplasma in, in India, 1582N

Steyer, S., $495 \mathrm{~N}$

Stier, J. C., 847

Stinking cedar. See Torreya taxifolia

Stojkovic, B., 491N

Stone, A. L., 945

Strauss, J., 1028N

Strawberry. See Fragaria $\times$ ananassa

Strawberry necrotic shock virus (SNSV), in strawberry, in China, 1198N

Strawberry tree. See Arbutus unedo

Strelitzia nicolai (bird of paradise), Acidovorax avenae subsp. avenae on, 1474N

Streptomyces turgidiscabies, on potato, lopsided oat green manure for suppression of, 1124

Stromberg, E. L., 19

Strømeng, G. M., 1031N

Su, S. C., 1314N

Subbarao, K. V., 784, 1224

Subramanian, S., $1195 \mathrm{~N}$

Suchá, J., 1197N

Suga, H., 1270

Sugar beet. See Beta vulgaris

Sugarcane. See Saccharum spp.

Sugarcane mosaic virus (SCMV), on corn, in

France, $70 \mathrm{~N}$

Sullivan, A., 113

Sullivan, C. M., 337

Sullivan, J. P., 612N

Sullivan, M. J., 876N

Sun, G., 368

Sun, Y. W., 78N

Sundaraj, S., 881N, 1520

Sundelin, T., 228N

Sundin, G. W., 921, 927

Sunflower. See Helianthus annuus

Surico, G., 74N

Sutton, B. D., $1475 \mathrm{~N}$

Sutton, T. B., 368, 1179

Suz, L. M., 1030N

Svoboda, J., 220N, 1321N

Swai, I. S., 768N

Sweet persimmon. See Diospyros kaki

Sweet potato. See Ipomea batatas

Sweet potato chlorotic stunt virus (SPCSV), in sweet potato, in China, 356N

Sweet potato leaf curl virus (SPLCV), in U.S. sweet potato germplasm collection, detection and classification of isolates, 1385

Sweet potato symptomless virus 1 and Sweet potato virus $\mathrm{A}$, in sweet potato, in Tanzania, $224 \mathrm{~N}$

Swiss chard. See Beta vulgaris

Switchgrass. See Panicum virgatum

Symphyotrichum novi-belgii, Golovinomyces cichoracearum on, in Denmark, $228 \mathrm{~N}$

Synchytrium spp.

on kudzu, in Korea, 358N

on yellow starthistle, 907

Systemic acquired resistance (SAR),

Xanthomonas citri subsp. citri on grapefruit and, 725

Szabo, L. J., 624, 1346

Szigethy, A., 1193N

Tabebuia impetiginosa (pink ipê), Rhizoctonia solani AG-4 on, in Italy, $78 \mathrm{~N}$

Tabima, J., $875 \mathrm{~N}$

Tairo, F., 224N

Takács, A., 363N

Takahashi, M., 1124

Tan, G. J., $1190 \mathrm{~N}$

Tanacetum cinerariifolium (pyrethrum),

Boeremia exigua var. exigua on, in Australia, $1478 \mathrm{~N}$

Tanaka, F. A. O., 104

Tang, M.-L., 616N

Tannins, Armillaria spp. growth and, 1255

Tao, X.-R., 1483N

Taro. See Colocasia esculenta

Tarragon. See Artemisia dracunculus

TASVd. See Tomato apical stunt viroid

Taufa, L., 70N

Taylor, J., 595

Taylor, N., 614N

Taylor, R. J., 691, 997

Tebuconazole, for Monilinia fructicola, 821

Teelucksingh, L. D., 1313N

Tefera, H., 492N

Temple, T. N., 423

Tenuta, A., 1346

Terefe, T., 611N

Teuber, F., 394
Tewoldemedhin, Y. T., 1153

Thekopsora minima, on blueberry in Mexico, 772N

in Michigan, $768 \mathrm{~N}$

Thiamethoxam, Xanthomonas citri subsp. citri on grapefruit and, 725

Thiophanate-methyl (THM), for Monilinia

fructicola, 821

THM. See Thiophanate-methyl

Thomason, W. E., 1458

Thomidis, T., 79N, 872N

Thummabenjapone, P., 1172

Tian, B., 945

Tian, S.-P., 63

Tian, W. X., 1070

Tian, Y.-T., 356N

Tillage

Colletotrichum graminicola on corn and, 601

detached tiller method for assessment of resistance to Rhizoctonia solani on rice, 1507

rice grain smuts and, 990

Tilletia spp.

$T$. contraversa, on wheat, induction and establishment under marginal climatic conditions, 478, cover photo: April

T. maclaganii, on switchgrass, in New York and Pennsylvania, $1587 \mathrm{~N}$

on organic wheat, control of, 92, cover photo: February

Timmerman, A. D., 73N

Tirpak, S., 78N

Tjamos, S. E., 223N, 777N

Tobacco. See Nicotiana spp.

ToCV. See Tomato chlorosis virus

Toda, T., 705

Todd, J. W., 263

Toit, L. J. du, 1492

ToLCNDV. See Tomato leaf curl New Delhi virus

Toloy, R. S., 104

Tomato. See Solanum lycopersicum

Tomato apical stunt viroid (TASVd), in

Brugmansia sp., in Belgium, 495N

Tomato chlorosis virus (ToCV)

new hosts of, in Costa Rica, 497N

in pepper, in Costa Rica, 1482N

in tomato

in Georgia, $881 \mathrm{~N}$

in Hungary, 363N

in Sudan, 1592N

Tomato leaf curl New Delhi virus (ToLCNDV), in cucumber, in Indonesia, $1485 \mathrm{~N}$

Tomato spotted wilt virus (TSWV)

in Gerbera hybrida, in Serbia, $226 \mathrm{~N}$

in pepper, in Montenegro, $882 \mathrm{~N}$

in tobacco, in Italy, $611 \mathrm{~N}$

Tomato yellow leaf curl virus (TYLCV) in cowpea, in China, 362N weed hosts of, in Cyprus, 120

Tomato zonate spot virus (TZSV), in tobacco, in China, 1484N, cover photo: November

Toppe, B., 355N

Tornos, T., $75 \mathrm{~N}$

Torres, R., 492N

Torreya taxifolia, novel Fusarium sp. on, 633

Towers, G., 492N

Toxoptera citricida (brown citrus aphid), Citrus tristeza virus and stem pitting and, 913

Trachycarpus fortunei (windmill palm),

Phytophthora palmivora and $P$. nicotianae on, in Italy, $768 \mathrm{~N}$

Trapero, A., 770N, 1139

Travis, J. W., 269

Tredway, L. P., 1131

Tree peony. See Paeonia suffruticosa

Tremblay, D.-M., 504

Trevisan, F., 1021 
Trichothecium roseum, on tomato, in Brazil, $1318 \mathrm{~N}$

Trigiano, R. N., 879N

Triticum aestivum (wheat)

distribution and prevalence of Fusarium crown rot and common root rot pathogens in, 1099

effect of location, cultivar, and diseases on grain yield of in Wisconsin, 1401

Fusarium spp. on

F. graminearum: corn residue as source of inoculum, 1458; grain harvesting strategies to minimize losses from, 1448; resistance to inital infection and spread by deoxynivalenol and nivalenol chemotypes of, 31 integrating cultivar resistance and fungicide application and, 554 F. pseudograminearum and Bipolaris sorokiniana on, population dynamics between using real-time qPCR, 1089

F. tricinctum, in Argentina, 496N

Heterodera avenae on, foliarly applied spirotetramat and, 983

Mycosphaerella graminicola on,

PROCULTURE model for, 384

organic, control of common bunt in, 92, cover photo: February

Puccinia graminis f. sp. tritici on isolates with virulence to resistance genes $S r 31$ and $S r 24,1591 \mathrm{~N}$ race TTKSK (Ug99), in Zimbabwe and Mozambique, $1188 \mathrm{~N}$

Puccinia triticina on effect of postsymptom application of fungicides on urediniospore production by, 325

Lr21 gene and, $1032 \mathrm{~N}$

physiologic specialization in U.S. in 2009, 935

in South Africa, $611 \mathrm{~N}$

Pyrenophora tritici-repentis on, detection of QoI fungicide-resistant isolates, 1558

rank-based method for improved cultivar selection, 1407

Stagonospora nodorum on, degree-day model for the latent period of, 561

Tilletia contraversa on, induction and establishment under marginal climatic conditions, 478, cover photo: April

Triticum mosaic virus in characterization of isolates in southern Great Plains, 1516

in Kansas, occurrence and yield effects, 183

Xanthomonas translucens pv. undulosa on, new sources of resistance in, 582

Triticum mosaic virus (TriMV), in wheat

characterization of isolates in southern Great Plains, 1516

in Kansas, occurrence and yield effects, 183

Trulock, A., 633

Tsai, W. S., $1197 \mathrm{~N}$

Tsay, J.-G., $1188 \mathrm{~N}$

Tsialtas, J. T., 1322N

Tsopelas, P., 223N, 777N

Tsuga canadensis (Eastern hemlock),

Sirococcus tsugae on, in Georgia, 612N

TSWV. See Tomato spotted wilt virus

TTKSK. See under Puccinia graminis f. sp. tritici

Tumbalam, P., 228N, 1194N

Tunali, B., 76N

Turechek, W. W., 360N, 1586N

Turfgrasses. See also Specific turfgrasses

Bipolaris oryzae on, in New York, 1192N

Bipolaris spicifera on, in United States, $1191 \mathrm{~N}$

fungi associated with fairy rings in, 1131
Microdochium spp. and Typhula spp. on, 839

Puccinia coronata on, in United States, 1547

Sclerotinia homoeocarpa on

effects of dew removal and mowing

frequency on fungicide performance, 1427

effects of plant growth regulators and mowing frequency on, 1433, cover photo: November

in vitro assessment of resistance to fungicides and plant growth regulators, 51

Waitea circinata on, 515, cover photo: May

Turgay, E. B., 495N

Turina, M., $882 \mathrm{~N}$

Turnip ringspot virus (TuRSV), in field

mustard, in Taiwan, $1036 \mathrm{~N}$

TuRSV. See Brassica chinensis

Twieg, E., 614N

Twizeyimana, M., 43

Tychon, B., 384

TYLCV. See Tomato yellow leaf curl virus

Typhula spp., on closely mown fescue and bentgrass, 839

TZSV. See Tomato zonate spot virus

Ubame oak. See Quercus phillyraeoides

Udayashankar, A. C., $881 \mathrm{~N}$

Udupa, S. M., 1192N

Ug99. See under Puccinia graminis f. sp. tritici

Ulam raja. See Cosmos caudatus

Uma Maheswari, C., 1482N

Ünal, F., 495N

Untiveros, M., 355N

Uremis, I., $1035 \mathrm{~N}$

Urtica dioica (common nettle), Heterodera ripae on, in Spain, $883 \mathrm{~N}$

Ustilaginoidea virens, on rice, long-term crop rotation, soil tillage, fertility and severity of, 990, cover photo: August

UV protectants, Pichia anomala strain K, for control of apple blue mold and, 311

Vaccinium spp.

V. corymbosum (blueberry)

Botryosphaeria dothidea on, in Korea, $227 \mathrm{~N}$

Calonectria colhounii on, in United

States, $1187 \mathrm{~N}$

Fusarium proliferatum on, in Argentina, $1478 \mathrm{~N}$

Pythium sterilum on, in United States, $614 \mathrm{~N}$

Sclerotinia sclerotiorum on, in

Argentina, $774 \mathrm{~N}$

Thekopsora minima on: in Mexico,

$772 \mathrm{~N}$; in Michigan, $768 \mathrm{~N}$

V. macrocarpon (cranberry),

Gliocephalotrichum bulbilium on, in New Jersey, 618N

V. myrtillus (bilberry), Phytophthora

ramorum on, in Norway, $355 \mathrm{~N}$

Vadamalai, G., 491N, 1312N, 1474N

Vahdat, A., 38

Valdovinos-Ponce, G., 772N

Valencia, A. L., 492N, 1193N

Valkonen, J. P. T., 224N

Vallad, G. E., 461, 1224

van der Waals, J. E., 363N

van Heerden, S. W., 767N

Van Hemelrijck, W., 1029N

Vanneste, J. L., 70N, 1311N

Vargas, A., 875N

Vargas, J. A., 1482N

Varvaro, L., $221 \mathrm{~N}$

Vazquez, A., 878N

Vázquez-Euán, R., 256

Veerakone, S., 775N, 1484N
Vejražka, K., 79N

Velasco, P., 292

Velasquez, N. V., 331

Veloukas, T., 1302

Venturia spp.

$V$. inaequalis, on apple

QoI fungicide resistance, G143A

mutation and, 927

resistance to multiple fungicides, 921 , cover photo: August

$V$. pyrina, evaluation of six models to

estimate ascospore maturation in, 279

Vera Cruz, C. M., 441

Verbascum blattaria (moth mullein),

Golovinomyces cichoracearum on, in Italy, $225 \mathrm{~N}$

Verdier, V., 72N, 441

Verkley, G. J. M., 1313N

Verma, V. S., $1587 \mathrm{~N}$

Verniere, C., $774 \mathrm{~N}, 1312 \mathrm{~N}$

Vernière, C., $1311 \mathrm{~N}$

Verticillium spp.

V. dahliae

on Coleus verschaffeltii, in Italy, $878 \mathrm{~N}$

colorimetric microtiter bioassay for

fungicide sensitivity evaluation, 248

on cosmos, in California, $361 \mathrm{~N}$

lack of correlation between genotypic diversity and virulence phenotypes, 1224

on lettuce, 784 , cover photo: July

on potato, management with suppressive green manures, previous cropping history and, 568

on skullcap, 1147, cover photo: September

detection of multiple species in soil using

density flotation and real-time PCR, 1571

V. nigrescens, on alfalfa, in China, $1591 \mathrm{~N}$

Vetch, wild. See Vicia spp.

Viana, F. M. P., 793

Viburnum tinus, Alfalfa mosaic virus in, in

Chile, $1198 \mathrm{~N}$

Víchová, J., 79N

Vicia spp. (wild vetch), branched broomrape on, in Greece, $1322 \mathrm{~N}$

Vieira, M. L. C., 1021

Vigna radiata (mungbean), Macrophomina

phaseolina on, in China, $872 \mathrm{~N}$

Vigna sinensis (cowpea), Tomato yellow leaf curl virus in, in China, $362 \mathrm{~N}$

Viljoen, A., 951

Villalta, O., 279

Villani, S., $1589 \mathrm{~N}$

Villani, S. M., 828, 1584N

Vincetoxicum spp. (swallow-worts),

Colletotrichum lineola on, from Russia,

$1586 \mathrm{~N}$

Vinh, V. N., 1063

Viremouneix, T. R., 357N

Viroids

Chrysanthemum chlorotic mottle viroid, in chrysanthemum, in China, $1320 \mathrm{~N}$

Chrysanthemum stunt viroid, in

Argyranthemum frutescens, in France, $1196 \mathrm{~N}$

Citrus viroid IIII, in citrus, in New Zealand,

$775 \mathrm{~N}$

COLEUS blumei viroid 2 in coleus, in

China, 494N

grapevine yellow speckle viroid 1, in grape,

in New Zealand, 617N

Hop stunt viroid

in cucumber, $615 \mathrm{~N}$

in grape, in New Zealand, $617 \mathrm{~N}$

Peach latent mosaic viroid, in peach, quantitative real-time PCR for, 137

Pear blister canker viroid, in pear, in Argentina, 882N 
Tomato apical stunt viroid, in Brugmansia sp., in Belgium, $495 \mathrm{~N}$

Viruega, J. R., 1139

Visser, B., 611N, 1188N

Vital, K., 774N, 1311N, 1312N

Vitale, A., 195, 877N, 1588N

Vitis spp.

Erysiphe necator on, variation within and among species for host resistance, 202

as hosts for Grapevine leafroll-associated virus-2 and -3 and Grapevine virus $a$ and $b, 657$

Vitis vinifera (grape)

Botryosphaeria spp. on, in China, 219N, $616 \mathrm{~N}$

Botrytis cinerea on in Chile, 683 gibberellic acid for management of, 269

Campylocarpon fasciculare on, in Spain, $1028 \mathrm{~N}$

Colletotrichum acutatum on, detection and monitoring by real-time PCR, 298

Cryptovalsa ampelina on, in Chile, $490 \mathrm{~N}$

Cylindrocarpon pauciseptatum on, in Spain, $361 \mathrm{~N}$

Diplodia corticola on, in Spain, $1315 \mathrm{~N}$

Elsinö̈ ampelina on, model to estimate amount of primary inoculum of, 1167

Eutypella leprosa on, in Chile, $490 \mathrm{~N}$

fungal trunk pathogens in propagation process for, 1040

Grapevine leafroll-associated virus 1 in, in Washington state, $613 \mathrm{~N}$

Grapevine yellow speckle viroid 1 and Hop stunt viroid in, in New Zealand, 617N

Greeneria uvicola on, detection and monitoring by real-time PCR, 298

Neofusicoccum spp. on in Chile, $1032 \mathrm{~N}$ in Spain, $876 \mathrm{~N}, 1315 \mathrm{~N}$

Phaeoacremonium spp. on in Iran, 1034N in Spain, 615N

phytoplasma diseases on, in Croatia, 353N

weeds in as potential hosts of black-foot and petri disease pathogens, 803

Xylella fastidiosa on, effect of abscisic acid application on, 173

Vossbrinck, C. R., 496N

Vrandecic, K., 612N

Vu, A. L., 1191N, 1195N, 1585N

Vucurovic, A., 226N, 491N, 1035N

Vuorinen, M., 875N

Vuuren, S. P. van, 1026N

Wade, M. L., 448

Wadl, P. A., 879N

Wairuri, C. K., 363N

Waitea circinata

var. circinata

on creeping bentgrass: in Arizona, 492N; in New Jersey, 78N

on turfgrasses, in New Jersey, 78N

var. prodigu, on kikuyugrass, in California, $767 \mathrm{~N}$

on seashore paspalum, 515, cover photo: May

Walber, T. M., 224N

Walcott, R. R., 697

Waldrop, T. A., 811

Wall, M. M., 360N

Wallhead, M., 1448

Walnut. See Juglans spp.

Walnut witches'-broom phytoplasma (WWB),

on Japanese walnut, in Iowa, 1474N

Walsh, D. J., 595

Walters, D. R., 595

Wang, B., $1318 \mathrm{~N}$

Wang, C. X., 1316N
Wang, F., 1070, 1378

Wang, G. P., 1319N, 1483N

Wang, H. Q., 494N

Wang, H.-C., 612N

Wang, H.-L., 1188N

Wang, J., 769N, 1314N

Wang, J. T., 1197N

Wang, L. L., 1314N

Wang, L. P., 1319N

Wang, M. L., 1385

Wang, M. X., 1591N

Wang, M.-S., 612N

Wang, W., 771N

Wang, W.-L., 1188N

Wang, X., 769N

Wang, X. M., 872N

Wang, X. X., 1318N

Wang, X.-L., 219N, 1026N

Wang, Y., 359N

Wang, Y. H., 73N

Wang, Y.-J., 356N

Wang, Z.-Y., 219N, 616N

Wanyera, R., 762

Ward, L. I., $617 \mathrm{~N}$

Warfield, C. Y., 872N

Wargo, P. M., 1255

Water displacement method, WinRHIZO rootscanning method vs., plant root parameter assessment and, 1308

Watergrass, late. See Echinochloa oryzicola

Waterhemp. See Amaranthus spp.

Watermelon. See Citrullus lanatus

Watermelon mosaic virus (WMV), in cucurbits, genetic diversity in Slovakia and Iran, 38

Waxflower, long-leaf. See Philotheca myoporoides

Waxman, K. D., 1032N, 1189N, 1192N

WBOL. See Candidatus Phytoplasma aurantifolia

WDV. See Wheat dwarf virus

Webber, J. F., 13

Weber, R. W. S., 368, 1263

Webster, C. G., 360N, 755, 881N, 1586N

Weeda, S. M., 1592N

Weems, J. D., 1318N

Weger, J., 497N

Wegulo, S. N., 554

Wei, B., $1320 \mathrm{~N}$

Wei, M., 1320N

Wei, X.-P., $1483 \mathrm{~N}$

Wei, Y., 360N

Weiland, J. E., 547

Weng, B.-C., $1188 \mathrm{~N}$

Werkman, A. W., $615 \mathrm{~N}$

West, J., 358N

Wheat. See Triticum aestivum

Wheat dwarf virus (WDV), in wheat and barley,

in Syria, Psammotettix provincialis and, 76N

Wheat streak mosaic virus (WSMV), in wheat, remote sensing of, 4

White, T. L., 461

Wick, R. L., 1255

Widmer, T. L., 907

Wilhelm, M., 158, 166

Willani, S. A., 354N

Williams, M. M. II, 1492

Willocquet, L., 1204, 1507

Willow, white. See Salix alba

Wilmshurst, C. J., 1217

Windmill palm. See Trachycarpus fortunei

WinRHIZO root-scanning method, water displacement vs., plant root parameter assessment and, 1308

Winska-Krysiak, M., 493N

Winter, S., $1321 \mathrm{~N}$

Wipf-Scheibel, C., 153

Wise, K., 325

Wisteria sinensis (Chinese wisteria), Nigrospora sphaerica on, $219 \mathrm{~N}$
Witches'-broom diseases. See also Candidatus

Phytoplasma spp.

of Arabian pea, in Australia, 226N

of Japanese walnut, in Iowa, 1474N

of soybean, $16 \mathrm{SrII}$ group phytoplasma and,

492N, cover photo: April

WMV. See Watermelon mosaic virus

Woelk, C. I., 614N

Wolday, A., 1591N

Wong, D. K. W., 360N

Wong, F. P., 492N, 767N

Wonni, I., 72N

Workneh, F., 4

Wright, D. L., 317, 744

Wright, E. R., 1478N

WSMV. See Wheat streak mosaic virus

Wu, P. S., $880 \mathrm{~N}, 1586 \mathrm{~N}$

Wulff, N. A., 104

Xanthomonas spp.

F. arboricola pv. juglandis, on walnut, 1565

F. arboricola pv. pruni bio-PCR protocol for detection of, 1109 on cherry laurel, in Italy, 74N

$F$. axonopodis pv. poinsetticcola, on poinsettia, $70 \mathrm{~N}, 1187 \mathrm{~N}$, cover photo: January

F. campestris pv. campestris, on Brassica napus, sources of resistance to, 292

on cashew, polyphasic characterization of pigmented strains, 793

F. citri pv. citri

on grapefruit, imidacloprid, thiamethoxam, and acibenzolar- $S$ methyl for control of, 725 on grapefruit and Mexican lime, in Senegal, $1311 \mathrm{~N}$

F. citri pv. mangiferaeindicae, on mango in Burkina Faso, 1312N in Ghana, 774N

F. gardneri, on tomato, in Ohio and

Michigan, $1584 \mathrm{~N}$

F. oryzae pv. oryzae on African cultivated rice, 441 on rice, real- time bio-PCR using pathovar-specific primers, 589

F. oryzae pv. oryzicola, on rice, in Burkina Faso, $72 \mathrm{~N}$

F. translucens pv. undulosa, on wheat, new sources of resistance in, 582

Xia, H., 219N, 1026N

Xia, J. R., $871 \mathrm{~N}$

Xiang, M. M., 1030N

Xiao, C. L., 72N, 1075

Xie, C., 113

Xie, G. L., 1070

Xie, Y., 616N, 771N

Xing, X., 431

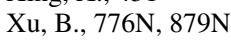

$\mathrm{Xu}$, B. C., $1319 \mathrm{~N}$

$\mathrm{Xu}, \mathrm{D} ., 1031 \mathrm{~N}$

$\mathrm{Xu}, \mathrm{J} ., 774 \mathrm{~N}$

$\mathrm{Xu}$, J. S., 774N

$\mathrm{Xu}, \mathrm{L} ., 73 \mathrm{~N}$

$\mathrm{Xu}, \mathrm{W} . \mathrm{X} ., 1483 \mathrm{~N}$

Xylella fastidiosa

on almond

analysis of xylem fluid in cultivars differing in resistance to, 166

influence of inoculation date on, 158

on grape, effect of abscisic acid application on, 173

on peach, in New Mexico, $871 \mathrm{~N}$

Yadav, S., 1582N

Yago, J. I., 1590N

Yam. See Dioscorea spp.

Yam mild mosaic virus (YMMV), in yam, in China, 1320N 
Yamamoto, P. T., 104

Yan, G., 226N

Yan, G. P., 983

Yan, J., $880 \mathrm{~N}, 1586 \mathrm{~N}$

Yan, J.-Y., 219N, 616N

Yánez, J. M., 1233

Yang, C., 357N

Yang, H., 1198N

Yang, J., 1063

Yang, J. R., 1591N

Yang, K. Q., 773N

Yang, S. Y., 1314N

Yang, X. B., 485

Yao, M., 1483N

Yao, S., 871N

Yao, S.-W., $616 \mathrm{~N}$

Ye, S. T., $1318 \mathrm{~N}$

Yeater, K. M., 990

Yellow starthistle. See Centaurea solstitialis

Yildirim, A. F., 495N

Yin, J., 490N

Yin, L. F., 225N

Yin, Y., 357N

Yoder, K. S., 368

You, M. P., 1590N

Young, H. M., 744

Yu, J., 70N, 1311N

Yu, R. H., 769N

Yu, Z. Z., 226N

Yuen, J., 1204

Yuen, J. E., 839

Yüksel, C., $495 \mathrm{~N}$

Yun, H. O., 220N

Yun, H. Y., 358N, 770N, 1474N

Zahn, M., 394

Zaid, A. M., $1581 \mathrm{~N}$

Zainal Abidin, M. A., 1474N

Zale, J., 1191N
Zambino, P. J., 1314N

Zambolim, E. M., 1194N

Zambolim, L., 1194N

Zea mays (corn)

Aspergillus flavus on, atoxigenic isolates to

reduce contamination of maize in Kenya,

212

Cercospora zeae-maydis on, QoI fungicideresistant, 189

Clavibacter michiganensis subsp. nebraskensis on, in Texas, 73N

Colletotrichum graminicola on, tillage, crop

rotation, and hybrid effects on, 601

disease reactions of hybrids in disease

nurseries, 1492

Fusarium graminearum on, in South Africa, 1153

Maize dwarf mosaic virus and Sugarcane mosaic virus on, cover photo: December residues of, as inoculum source of Fusarium graminearum on wheat, 1458

Sugarcane mosaic virus on, in France, $70 \mathrm{~N}$

Zearfoss, A. D., 561

Zeng, R., 354N, 362N

Zhang, C. Q., 1319N

Zhang, D.-S., 356N

Zhang, G. Q., 1070

Zhang, G. R., 1318N

Zhang, H., 774N

Zhang, H.-M., 1063

Zhang, J. Q., 872N

Zhang, L., 357N

Zhang, L. L., 879N

Zhang, L. X., 1190N

Zhang, N., 78N

Zhang, P., 431

Zhang, Q. E., $880 \mathrm{~N}, 1586 \mathrm{~N}$

Zhang, R., 368

Zhang, S., 461, 880N
Zhang, W., 1026N, 1035N

Zhang, Y., 611N

Zhang, Y. X., 1030N

Zhang, Z., 357N, 777N, 871N

Zhang, Z. Z., $1320 \mathrm{~N}$

Zhang, Z.-C., 356N

Zhang, Z.-K., 357N

Zhao, D., 640

Zhao, L., 1378

Zhao, Z. Y., 879N

Zheng, L., 359N, 1190N

Zheng, X. H., 776N

Zheng, Y.-X., 354N

Zhi, Y., 493N

Zhou, G.-H., 1063

Zhou, J. F., 1319N, 1483N

Zhou, W.-L., 1483N

Zhou, X. P., 776N

Zhu, B., 1070

Zhu, H.-J., $219 \mathrm{~N}$

Zhu, X.-Q., 1284

Zhu, Z., 1190N

Zhu, Z. D., 872N

Zindovic, J., $882 \mathrm{~N}$

Zinnia, Golovinomyces cichoracearum on, in

Turkey, $1317 \mathrm{~N}$

Zou, C., 1320N

Zouhar, M., 353N

Zovko, M., 883N

Zucchini yellow mosaic virus (ZYMV),

experimental verification of seed transmission of, 751

Zuo, R.-J., $1484 \mathrm{~N}$

Zwart, D. C., 811

Zwolinska, A., $1475 \mathrm{~N}$

Zygophiala wisconsinensis, on sweet persimmon, in Korea, $616 \mathrm{~N}$

ZYMV. See Zucchini yellow mosaic virus 